\title{
COMMENTS
}

\section{The Initiative and Referendum's \\ Use in Zoning}

\author{
Craig N. Oren $\dagger$
}

In recent years, there has been a surge of litigation involving the validity of the use of the initiative and referendum in zoning. The author examines the various arguments against allowing the initiative and referendum's use, and concludes that an adequate case has not been made for prohibiting these devices in zoning.

American courts are divided on whether voters may use the initiative $^{1}$ to enact, or the referendum ${ }^{2}$ to challenge, municipal zoning meaLaw.

$\dagger$ A.B. 1973, University of California; third-year student, Boalt Hall School of

1. The initiative permits the direct enactment of legislation by the voters. A proposed measure is placed on the ballot upon certification of petitions bearing the required number of signatures (generally ranging from five to $25 \%$ of registered voters). For examples of initiative procedures, see CaL. Elec. Code $\$$ 4000-23 (West Supp. 1975), implementing CaL. CoNST. art. IV, § 25; N.J. STAT. ANN. \$§ 40:69A-184 to -196 (1967); OHо R.C.A. \$§ 731.28-.4 (Page 1953), implementing Oно CoNST. art. II, \& 1f. The local legislative body often has the option of passing a proposed initiative measure after certification rather than placing it on the ballot. See, e.g., CAL. ELEC. CODE $\$ \S$ 4011-12 (West Supp. 1975); N.J. STAT. ANN. \& 40:69A-191 (1967). Amendment of the initiative measure by the legislative body after passage is often restricted. See, e.g., CaL. ELEC. CoDe \& 4015 (West 1968); Nev. R.S. \& 295.025 (1973).

2. The referendum allows voters to force an ordinance passed by the local legislative body to be submitted for a vote of the people. Opponents of a proposed ordinance typically must file a petition bearing the required number of signatures between final passage and the ordinance's effective date (often 30 days after passage). If the ordinance is not promptly repealed by the legislative body, its operation is suspended and it is placed on the ballot for popular vote. See, e.g., CaL. Elec. Code \$\$ 4050-57 (West Supp. 1975). The referendum procedure supplements the initiative, which can be used to propose the repeal of an existing ordinance.

The initiative and referendum both stem from the Progressive movement of the 1900's. Progressives believed that the initiative and referendum and similar devices would:

deprive machine government of the advantages it had in checkmating popular control, and make government accessible to the superior disinterestedness of the average citizen. Then, with the power of the bosses broken or crippled, it would be possible to check the incursions of the interests upon the welfare of the people and realize a cleaner, more efficient government.

R. Hofstadter, THE AGE OF REForm 225 (1955). Controversy has raged over whether the initiative and referendum indeed accomplish these goals. See, e.g., W. CROUCH, THB Initiative and Referendum in California 21-25 (1950); H. Croly, Progressive Democracy 306 (1914); W. Munro, The Government of American Cities (4th ed. 1939). 
sures. ${ }^{3}$ Courts have invalidated use of the initiative in zoning as a violation of procedural due process rights of property owners, ${ }^{4}$ as an impermissible delegation of legislative power, ${ }^{5}$ and as a void attempt to circumvent state laws establishing procedures for passage of zoning measures. ${ }^{6}$ The referendum's application to zoning has been nullified as an impermissible extension into the "admimistrative" rather than "legislative" realm. ${ }^{7}$

California courts have allowed the voters of any locality to challenge zoning measures by referendum. ${ }^{8}$ On initiative zoning ineasures, however, the courts have distinguished between charter cities, which have broad power over mumicipal affairs, ${ }^{9}$ and counties and general law cities, ${ }^{10}$ whose zoning power is governed by the State Zoning Law's

3. "Zoning is governmental regulation of the uses of land and buildings according to districts and zones ..... Fire limits, height districts and building regulations are forms . . . of zoning." E. MCQuilitin, Municipal Corporations $\$ 25.01$ (rev. ed. 1965). Zoning was originally advocated as a means of protecting residential property values by preventing a single-family district, for instance, from being blighted by the presence of industry. See, e.g., Advisory COMMTtTEE ON ZONING, U.S. DeP'T OF COMMERCE, A Zoning Primer (1926); J. Metzendaum, The Law of Zoning 6 (1930). After several years of controversy, the constitutionality of zoning was upheld in Village of Euclid v. Ambler Realty Co., 272 U.S. 365 (1926).

4. See, e.g., Taschner v. City Council, 31 Cal. App. 3d 48, 107 Cal. Rptr. 214 (4th Dist. 1973) (alternative holding); People's Lobby v. Board of Supervisors, $30 \mathrm{Cal}$. App. 3d 869, 106 Cal. Rptr. 666 (1st Dist. 1973) (alternative holding). These decisions were silently disapproved by the California Supreme Court on this point in San Diego Building Contractors v. City Council, 13 Cal. 3d 205, 529 P.2d 570, 118 Cal. Rptr. 156 (1974), appeal filed, 43 U.S.L.W. 3626 (U.S. May 20, 1975) (No. 74-1459).

5. See City of Scottsdale v. Superior Court, 103 Ariz. 204, 207-08, 439 P.2d 290, 293 (1968) (alternative holding).

6. See, e.g., Hurst v. City of Burlingame, 207 Cal. 134, 277 P. 308 (1929); Korash v. City of Livoma, 388 Mich. 737, 202 N.W.2d 803 (1972); State ex rel. Powers v. Donohue, 368 S.W.2d 432 (Mo. 1963).

7. West v. City of Portage, 392 Mich. 458, 221 N.W.2d 303 (1974); Kelley v. John, 162 Neb. 314, 75 N.W.2d 713 (1956), noted in 5 UTAH L. Rev. 413 (1956); Forman v. Eagle Thrifty Drugs \& Market, Inc., 89 Nev. 533, 516 P.2d 1234 (1973).

8. See, e.g., Dwyer v. City Council, 200 Cal. 505, 253 P. 932 (1927) (charter city); Johnston v. City of Claremont, 49 Cal. 2d 826, 323 P.2d 71 (1958) (general law city).

9. Sectiou 3 of article XI of the California Constitution allows any city to adopt a charter by majority vote of the electorate. The charter may grant to the city council the power to pass laws relating to municipal affairs. Such laws override contrary state statutes. CaI. CoNST. art. XI, § 5(a); Bishop v. City of San Jose, 1 Cal. 3d 56, 61, 460 P.2d 137, 140, 81 Cal. Rptr. 465, 468 (1969). On what constitutes a municipal affair, see Sato, Municipal Affairs in California, 60 CALIF. L. Rev. 1055 (1972).

10. General law cities have the power to pass local ordinauces, but are subject in all matters to contrary state law. CAI. Const. art. XI, $\$ 7$. Of the 412 California municipalities, 336 are general law. This may appear surprising in view of the relative ease of becoming a charter city. One explanation is the limited taxing power of a general law city as compared to a charter city, which often leads voters to oppose passage of a charter. For instance, Davis, California, recently rejected overwhelmingly the proposed initiation of steps to pass a charter because of concern that the city council would use 
procedural requirements. ${ }^{11}$ The voters of charter, but not of general law, cities have been allowed to pass zoning measures by initiative. ${ }^{12}$ The rule as to charter cities was recently reaffirmed in San Diego Building Contractors v. City Council, ${ }^{13}$ when the California Supreme Court, in a 4-3 decision, rejected the contention that the passage of zoning measures by initiative violates the procedural due process rights of property owners. ${ }^{14}$ The court has also agreed to review Associated Home Builders v. City of Livermore, ${ }^{15}$ a district court of appeal decision denying the zoning initiative to voters of a general law city.

If the number of reported cases is a guide, there has been a dramatic mcrease in the use of the initiative and referendum processes in zoning during recent years. ${ }^{16}$ Judging from the reported cases, the initiative and referendum are nearly always used in zoning to attempt to curb residential or commercial developinent, either through the enactment of general growth restrictions ${ }^{17}$ or through measures designed to

charter powers to pass a utility users' tax. Telephone interview with William Keiser, League of California Cities, Sacramento, California, April 9, 1975.

11. CaL. Gov'T CoDE $\S \S 65800-95$ (West 1968). The passage of a zoning ordinance of the type specified in section 65850 must be preceded by public hearings before a planning commission and local legislative body. CAL. Gov'T CoDe $§$ 65853-57 (West Supp. 1975).

12. Compare Bayless v. Limber, 26 Cal. App. 3d 463, 102 Cal. Rptr. 647 (2d Dist. 1972) (charter city) with Laguana Beach Taxpayers Ass'n v. City Council, 187 Cal. App. 2d 412, 9 Cal. Rptr. 775 (4th Dist. 1960) (general law city).

13. 13 Cal. 3d 205, 529 P.2d 570, 118 Cal. Rptr. 146 (1974), appeal filed, 43 U.S.I.W. 3626 (U.S. May 20, 1975) (No. 74-1459).

14. Id. at 210-18, 529 P.2d at 573-78, 118 Cal. Rptr. at 149-54.

15. 116 Cal. Rptr. 326 (1st Dist. 1974), hearing granted, Nov. 8, 1974.

16. In California, for instance, eight cases involving the use of the initiative and referendum in zoning have been reported since 1970. Southern Alameda Spanish Speaking Organizations v. City of Umion City, 314 F. Supp. 967 (N.D. Cal.), aff'd, 424 F.2d 291 (9th Cir.), final order entered, 357 F. Supp. 1188 (N.D. Cal. 1970); San Diego Building Contractors v. City Council, 13 Cal. 3d 205, 529 P.2d 570, 118 Cal. Rptr. 146 (1974); Builders Ass'n v. Superior Court, 13 Cal. 3d 225, 529 P.2d 582, 118 Cal. Rptr. 158 (1974), appeal filed, 44 U.S.L.W. 3062 (U.S. July 29, 1975) (No. 75-111); Associated Hoine Builders v. City of Livermore, 116 Cal. Rptr. 326 (1st Dist. 1974), hearing granted, Nov. 8, 1974; Taschner v. City Council, 31 Cal. App. 3d 48, 107 Cal. Rptr. 214 (4th Dist. 1973); People's Lobby, Inc. v. Board of Supervisors, 30 Cal. App. 3d 869, 106 Cal. Rptr. 666 (1st Dist. 1973); Duran v. Cassidy, 28 Cal. App. 3d 574, 104 Cal. Rptr. 793 (5th Dist. 1972); Bayless v. Limber, 26 Cal. App. 3d 463, 102 Cal. Rptr. 647 (2d Dist. 1972). This figure probably understates the frequency of the initiative and referendum's use, since it is often economically burdensome and ultimately futile to challenge zoning procedure. See R. BABCOCK, THE ZonING GAME 13 (1966).

17. See, e.g., San Diego Building Contractors v. City Council, 13 Cal. 3d 205, 529 P.2d 570, 118 Cal. Rptr. 146 (1974) (building height limitation in coastal zone); Builders Ass'n v. Superior Court, 13 Cal. 3d 225, 529 P.2d 582, 118 Cal. Rptr. 158 (1974), appeal filed, 44 U.S.L.W. 3062 (U.S. July 29, 1975) (No. 75-111) (freeze on residential development if certain conditions were not satisfied); People's Lobby, Inc. v. Board of Supervisors, 30 Cal. App. 3d 869, 106 Cal. Rptr. 666 (1st Dist. 1973) (ban on construction in coastal zone). 
halt a specific proposed development. ${ }^{18}$ For proponents of "no-growth," the initiative and referendum processes have become a means of counteracting the frequent pro-development bias of local officials. ${ }^{19}$

Aside from their use in achieving particular results, the initiative and referendum can play a valuable role in the land use process. An initiative or referendum campaign tends to act as an educational force which directs popular attention toward a specific issue of concern. ${ }^{20}$ It provides an outlet for groups which cannot form the kind of broad, long-lived coalitions necessary for taking control of a representative body, but are capable only of the relatively sporadic and issue-oriented focus demanded by an initiative or referendum campaign. Moreover, in a nation whose political system is based upon the consent of the governed, the initiative and referendum are valuable means of legitimating governmental decisionmaking on controversial matters.

Zoning is in some respects a umquely apt subject for initiative and referendum. Zoning decisions often spark more controversy than any other kind of governmental policy choice, ${ }^{21}$ citizens correctly perceive that both the value of their property and the desirability of the community as a place to reside are strongly affected by land use choices. Public debate on zoning issues is thus likely to be vigorous, aiding the voters in making an imtelligent decision. Moreover, since zoning decisions are made at the local level, there is little need for the large sums of money necessary for gathering petition signatures and campaigning on a statewide scale. ${ }^{22}$

18. See, e.g., Southern Alameda Spanish Speaking Organization v. City of Union City, 314 F. Supp. 967 (N.D. Calif. 1970) (setting aside zoning for multi-family lowincome development); Smith v. Township of Livingston, 106 N.J. Super. 444, 256 A.2d 85 (Super. Ct., Ch. Div.) aff'd mem., 54 N.J. 525, 257 A.2d 698 (1969) (rezoning to prevent shopping center); Kelley v. John, 162 Neb. 319, 75 N.W.2d 713 (1956) (protesting rezoning for Safeway store).

19. See JonNt COMM. on Open Space Land, Final Report 42-47, 100 (reprinted in 1 Appendix to Senate Journal, 1970 Reg. Sess. California Legislature), suggesting that many planning commissions and other zoning officials are frequently involved in conflicts of interest; Hagman, A New Deal: Trading Windfalls for Wipeouts, PLANnIng, Sept., 1974, at 11: "Members of the real estate industry are unduly interested in public service. The real estate industry should be represented on planning bodies. Society needs their expertise. But too many are there with private interests in public clothing."

20. See W. Crouch, The Initiative and Referendum in California 32-35 (1950). For an analysis of the adversary nature of a sample of initiative campaigns, see Radin, Popular Legislation in California: 1936-46, 35 CALIF. L. Rev. 171 (1947).

21. See R. Babcock, The Zoning Game (1966).

22. In the campaign on an initiative growth restriction measure in Livermore, California, the measure's advocates spent $\$ 2800$, while opponents spent $\$ 6700$. The latter's expenses were somewhat increased by the need to conduct a simultaneous campaign against a similar ordinance in a nearby town. In an election marked by a large voter turnout, the measure passed 6300 to 5200 . Report on File in the Office of the City Clerk, Livermore, California. For a general account of the Livermore campaign, see 
This Comment will assess the legal and practical objections that have been made to allowimg zoning via the initiative and referendum. It will conclude that an adequate case has not been made for categorically prohibiting the use of these devices in zoning. Those aggrieved by the results of zoning initiatives and referenda will therefore have to contest the validity of the ordinance itself rather than the procedure used in enactment. Indeed, in some cases the substance of initiative and referenduin zoning, not nrerely the procedure used, has been challenged. ${ }^{23}$

I

\section{Procedural Due Process in the Passage Of Zoning MeAsures}

Opponents of the zoning initiative have contended that property owners have a right under the fourteenth amendment's due process clause to notice and a public hearing prior to passage of a zoning ordinance. Since the initiative procedure does not provide for notice and a hearing, the argument runs, the initiative's use in zoming is unconstitutional. Although this position was taken by Cahfornia district courts of appeal in People's Lobby, Inc. v. Board of Supervisors, ${ }^{24}$ Taschner v. City Council, ${ }^{25}$ and Associated Home Builders v. City of Livermore,$^{26}$ it was ultimately rejected by the California Supreme Court in San Diego Building Contractors v. City Council. ${ }^{27}$

This due process theory has not barred use of the referendum to prevent a zoning ordinance fron beconing effective. ${ }^{28}$ The referenduin follows a properly noticed hearing in the original passage of the ordinance, and is thus distinguishable from the initiative. ${ }^{20}$ This distinction,

Deutsch, Land Use Growth Controls: A Case Study of San Jose and Livermore, California, 15 Santa Clara Law. 1 (1974).

23. See, e.g., Southern Alameda Spanish Speaking Organization v. City of Union City, 314 F. Supp. 967, 973, (N.D. Cal.), aff'd 424 F.2d 291 (9th Cir. 1970) (referendum which prevented constrnction of low-incoine housing unsuccesfully challenged as racially motivated and a violation of equal protection for poor and minority persons); Builders Ass'n v. Superior Court, 13 Cal. 3d 225, 231-33, 529 P.2d 582, 58688, 118 Cal. Rptr. 158, 162-64 (1974), appeal filed, 44 U.S.L.W. 3062 (July 29, 1975) (No. 75-111) (initiative measure freezing zoning of land for residential use unsuccessfully challenged as violative of state law regulating zoning freezes and constitutional right to travel).

24. 30 Cal. App. 3d 869, 873-74, 106 Cal. Rptr. 666, 669-70 (1st Dist. 1973).

25. 31 Cal. App. 3d 48, 65-69, 107 Cal. Rptr. 214, 228-31 (4th Dist. 1973).

26. 116 Cal. Rptr. 326, 330 (1st Dist. 1974) hearing granted, Nov. 8, 1974.

27. 13 Cal. 3d 205, 529 P.2d 570, 118 Cal. Rptr. 146 (1974), appeal filed, 43 U.S.L.W. 3626 (U.S. May 20, 1975) (No. 74-1459).

28. Taschner v. City Council, 31 Cal. App. 3d 48, 62 n.10, 107 Cal. Rptr. 214, 226 n.10 (4th Dist. 1973).

29. Id; Johnston v. City of Claremont, 49 Cal. $2 \mathrm{~d} 826,836,323$ P.2d 71, 77 (1958). 
first advanced to reconcile the referendum with statutory hearing prerequisites, seems questionable in a due process context since, while a hearing is afforded, the hearing record may be disregarded in making the decision. ${ }^{30}$ Another distinction advanced is that a successful referendum leaves private property owners in the same position as before adoption of the original ordimance, and thus does not significantly interfere with land use. ${ }^{31}$ Even if the referendum is subject to the due process theory, the balancing test employed later in this section to validate the initiative's use ought also to apply to the referendunt.

\section{A. Historical Background}

Virtually every state zoning enabling act in the nation provides for a hearing before the enactment of land use restrictions. ${ }^{32}$ As a result, there has been scant judicial consideration of the constitutionality of zoning procedures, as contrasted with a large number of judicial opinions on the constitutionality of substantive zoning acts. Hearing provisions in state statutes and local ordinances stem largely from the Standard Zoning Enabling Act, $^{33}$ developed in 1924 by a commission sponsored by the United States Department of Commerce. Many states substantially copied the measure in adopting zoming enabling acts, ${ }^{34}$ and even California's State Zoning Law, ${ }^{35}$ which was adopted several years before the promulgation of the Standard Act, ${ }^{36}$ contains remarkably similar provisions mandating public hearings before a planning commission and the local legislative body prior to adoption. ${ }^{37}$ The Standard Act's authors did not cite the Constitution as their reason for requiring

30. But cf. K. Davis, Administrative Law Treatise $\$ \S 11.02-.06$ (1958), suggesting that the decisionmaker need only understand the issues and need not have read the record.

31. This explanation was implicitly accepted in Taschner, which distinguished the decision in Bayless v. Limber, 26 Cal. App. 3d 463, 102 Cal. Rptr. 647 (2d Dist. 1972) (upholding use of initiative), as involving a "delayed referendum." $31 \mathrm{Cal}$. App. 3d at 67, 107 Cal. Rptr. at 224. The Taschner court thus seemed to regard repeal of a zoning regulation as an insignificant interference with land use, at least where no property owner rehed on the zoning regulation.

32. R. ANDerson, AMerican LAW of ZoNing \$ 4.02 (1968); E. McQuLlin, Muuicipal CORPorations $\$ 25.251$ (rev. ed. 1965). For an example of zoning procedural requirements, see CAL. Gov'T CoDE $\$ \S 65853-57$ (West Supp. 1975).

33. Advisory Commitee on Zoning, U.S. Dep'T of Commerce, A Standard State Zoning Enabling Act $\$ 4$ (rev. ed. 1926). The act is out of print, but it is reproduced in J. Metzenbaum, The Laiv of Zoning 303-07 (1930); 3 C. Rathkopf, LAw OF ZONING \& PlanNing 100-1 to 100-6 (3d ed. 1956).

34. R. ANDERSON, AMERICAN LAW OF ZONING $\$ 3.11$ (1968); F. BAIR \& E. Bartley, The Text of a Model Zoning Ordinance iii (2d ed. 1960). In 1931, Karl Lohmann reported that 35 states had modeled their zoning acts after the Standard Act. K. Lohmann, Principles of City Planning 253 (1931).

35. CAL. Gov'T CoDE $\$ \$ 65800-951$ (West 1968).

36. Ch. 734, [1917] Cal. Stat. 1419.

37. Id. $\S 4$. 
notice and hearings; rather, they emphasized the value of giving citizens an opportunity to protest ordinance provisions as a means of preventing the passage of ill-considered zoning measures. ${ }^{38}$

Judicial inquiries into procedure for passing zoning ordinances have thus usually focused on whether the notice and hearing in the particular instance inet enabling act or charter requireinents. ${ }^{30}$ Because of the general rule that numicipalities possess no inherent power to zone, ${ }^{40}$ procedural requirements are often regarded as "jurisdictional" and are thus strictly enforced, ${ }^{41}$ even when no prejudice to a property owner is shown. ${ }^{42}$ In one decision, a zoning ordinance was struck down because only four days notice, instead of the required five, was given. ${ }^{43}$ Some courts, by way of dictun, have also justified strict enforcement as necessary to protect "due process" rights of the property owner. ${ }^{44}$ But other courts, in sustaining the notice and hearing given, have included dicta stating that notice and hearing requirenents are purely a inatter of legislative grace. ${ }^{45}$

In those rare instances where an enabling act or city charter does not provide for any prior notice or public hearing, courts have been divided on the constitutionality of the zoning procedure. ${ }^{40}$ Decisions declaring the procedure unconstitutional have uniformly failed to dis-

38. Advisory Commttee on Zoning, U.S. Dep'T of Commerce, A Standard State Zoning Enabling Act $\S 7$ (rev. ed. 1926). For the views of a drafter of the standard act, see E. BAsSETT, Zoning 34 (1936). See also E. McQuillin, MUNicipal CORPORATTONS $\$ 25.245$ (rev. ed. 1965).

39. See, e.g., Pyramid Corp. v. DeSoto County Bd. of Supervisors, 366 F. Supp. 1299 (N.D. Miss. 1973); Glaspey \& Sons v. Conrad, 83 Wash. 2d 707, 521 P.2d 1173 (1974); Bal Harbor Village v. State ex rel. Giblin, 299 So. 2d 611, 615-16 (3rd Dist. Fla. App. 1974).

40. E. MCQUILLIN, MunICTPAL CORPorations $\$ 25.35$ (rev. ed. 1965).

41. See, e.g., Holly Development, Inc. v. Board of County Comm'rs, 140 Colo. 95, 342 P.2d 1032 (1959); Ellion v. Ft. Lauderdale, 183 So. $2 d 193$ (Fla. 1966); Williams v. City of San Bruno, 217 Cal. App. 2d 480, 31 Cal. Rptr. 854 (1st Dist. 1963).

42. See, e.g., Kelly v. City of Philadelphia, $382 \mathrm{~Pa} .459,115$ A.2d 238 (1955).

43. Alderman v. Town of West Haven, 124 Conn. 391, 200 A. 330 (1938).

44. See, e.g., Hart v. Bayless Investmont \& Trading Co., 86 Ariz. 379, 346 P.2d 1101 (1959); Glaspey \& Sons v. Conrad, 83 Wash. 2d 707, 521 P.2d 1173 (1974).

45. See, e.g., Burke v. Board of Representatives, 148 Conn. 33, 166 A.2d 849 (1961); Ottinger v. Arenal Realty Co., 257 N.Y. 371, 178 N.E. 665 (1931) (per Cardozo, J.); Lawton v. City of Austin, 404 S.W.2d 649, 651 (Tex. Civ. App. 1966).

46. Cases holding the procedure invalid include Masters v. Pruce, 290 Ala. 58, 274 So. 2d 33 (1973); Bell v. Studdard, 220 Ga. 756, 141 S.E.2d 537 (1965). A squarely contrary decision is Prescott v. Pierce, 130 Misc. 63, 223 N.Y.S. 609 (Sup. Ct. 1927). The California Supreme Court upheld a zoning ordinance passed without notice and hearing in Brougher v. Board of Public Works, 205 Cal. 426, 271 P. 487 (1928). The court discussed only whether tho State Zoning Law applied to a charter city, and did not address petitioner's contention that notice was "indispensable" to the validity of a zoning law. Brief for Petitioners, Filed by Leave Granted at Oral Argument, at 16. Cf. Adler v. City Council, 184 Cal. App. 2d 763, 7 Cal. Rptr. 805 (2d Dist. 1960) (procedural amendment to zoning ordinance leld valid though passed without notice and hearing). 
cuss whether legislative proceedings are governed by the due process guarantees of the fourteenth amendment. ${ }^{47} \mathrm{As}$ is argued in a later section of this Comment, these guarantees apply only in adjudicative proceedings. 48

\section{B. The Prelude to San Diego: California Cases on the Right to be Heard}

The due process analysis in California zoning decisions has been no more precise. Though several California courts have declared that a property owner has a non-statutory right to a hearing before passage of a zoning ordinance, these statements were invariably dicta. ${ }^{49}$ Additionally, these opinions have often failed to indicate whether the hearing was coinpelled as a matter of constitutional law, or was necessary only to suit the court's notions of proper public policy. ${ }^{50}$

47. See, e.g., Bell v. Studdard, 220 Ga. 756, 141 S.E.2d 536 (1965); Sikes v. Pierce, 212 Ga. 567, 94 S.E.2d 427 (1956). Both cases rely primarily on conclusory dicta in earlier cases.

48. See notes 73-75 and accompanying text infra.

49. San Diego Building Contractors v. City Council, 13 Cal. $3 d$ 205, 216-17 n.6, 529 P.2d 570, 577 n.6, 118 Cal. Rptr. 146, 153 n.6 (1974). The cases making the statement are City of Escondido v. Desert Outdoor Advertising, Inc., $8 \mathrm{Cal} .3 \mathrm{~d} 785,790,505$ P.2d 1012, 1016, 106 Cal. Rptr. 172, 176, cert. denied, 414 U.S. 828 (1973) (upholding a general law city ordinance restricting billboards against claim that State Zoming Law requirements of notice and hearing had to be met before enactment; see discussion at notes 68-72 and accompanying text infra); Scott v. City of Indian Wells, 6 Cal. 3d 541, 548-49, 492 P.2d 1137, 1141-43, 99 Cal. Rptr. 745, 749-50 (1972) (holding that affected property owners outside municipality's boundaries had to be notified before hearing on granting of use permit; see discussion at notes 61-67 and accompanying text infra); Gilgert v. Stockton Port District, 7 Cal. 2d 384, 391, 60 P.2d 847, 850 (1936) (invalidating zoning ordinance passed by port district, which had neither constitutional nor statutory authority to zone); Hurst v. City of Burlingame, 207 Cal. 134, 141, 277 P. 308, 311 (1929); Associated Home Builders v. City of Livermore, 116 Cal. Rptr. 326, 330 (1st Dist. 1974), hearing granted, Nov. 8, 1974; Taschner v. City Council, 31 Cal. App. 3d 48, 65, 107 Cal. Rptr. 217, 228 (4th Dist. 1973); People's Lobby, Inc. v. Board of Supervisors, 30 Cal. App. 3d 869, 873, 106 Cal. Rptr. 666, 669-70. (1st Dist. 1973) (all invalidating attempts to zone by initiative in localities subject to the State Zoning Law on basis that Zoning Law requirements of notice and hearing had not been complied with); Silvera v. City of South Lake Tahoe, 3 Cal. App. 3d 554, 558, 83 Cal. Rptr. 698, 700 (3d Dist. 1970) (invalidating a general law city's "interim urgency" zoning measure which, the court held, in fact constituted a permanent zoning measure; thus the measure did not fit within the statutory exception to notice and hearing requirements of Gov't Code $\S 65858$ and was thus subject to the notice and hearing requirements of $\S \S 65853$ 57); Metro Realty v. County of El Dorado, 222 Cal. App. 2d 508, 518, 35 Cal. Rptr. 480, 487 (3d Dist. 1963) (upholding temporary urgency zoning ordinance passed without notice and hearing); Kissinger v. City of Los Angeles, $161 \mathrm{Cal}$. App. 2d 454, 464, 327 P.2d 10, 17-18 (2d Dist. 1958) (invalidating zoning ordinance passed without compliance with charter provisions for notice and hearing); Berrata v. Sales, $82 \mathrm{Cal}$. App. 324, 327, 255 P. 538, 540 (3d Dist. 1927) (invalidating zoning ordinance of city whose charter was construed to adopt State Zoning Law's notice and hearing provisions).

50. See, e.g., Kissinger v. City of Los Angeles, 161 Cal. App. 2d 454, 464, 327 P.2d 10, 17-18 (2d Dist. 1958), in which the court states: "Certainly sound common 
Three such opinions by the California Supreme Court-Hurst $v$. City of Burlingame, ${ }^{51}$ Scott v. City of Indian Wells ${ }^{52}$ and City of Escondido v. Desert Outdoor Advertising ${ }^{53}$ - have been particularly relied upon in the district court of appeal decisions invalidating the use of the initiative in zoning.

Hurst nullified an initiative zoming measure on the theory that since the State Zoning Law's procedures governed the zoning power of general law cities, no valid zoning ordinance could be passed without complying with the Zoning Law's provisions. ${ }^{54}$ The opinion went on to suggest that:

[w] hen the statute requires notice and hearing as to the possible effect of a zoning law upon property rights the action of the legislative body becomes quasi judicial in character and the statutory notice and hearing then becomes necessary in order to satisfy the requirements of due process and may not be dispensed witl1.55

Conceding for the sake of argument that a zoning hearing is quasijudicial (a contention discussed infra ${ }^{56}$ ), does the above quotation mean that the due process right is dependent upon the existence of a statute requiring notice and hearing? If so, such a "right" cannot be constitutional in origin, since the existence of a constitutional right does not depend upon statutory law prescribing procedures. The district court of appeal in Taschner, however, regarded the above statenient as recognition of a constitutional right to a hearing. ${ }^{57}$ The state supreme court in San Diego appears to have read the Hurst quotation more soundly as signifying that the right to a hearing depends upon a statute; ${ }^{58}$ since the State Zoning Law does not apply to a charter city such as San Diego, ${ }^{60}$ Hurst was therefore inapplicable. ${ }^{60}$

sense and wise public policy would require an opportunity for property owners to be heard before ordinances which substantially affect their property rights are adopted. ..."

51. 207 Cal. 134, 277 P. 308 (1929).

52. 6 Cal. 3d 541, 492 P.2d 1137, 99 Cal. Rptr. 745 (1972).

53. 8 Cal. 3d 785, 505 P.2d 1012, 106 Cal. Rptr. 172, cert. denied, 414 U.S. 828 (1973).

54. 207 Cal. at $138-39,277$ P. at 310 .

55. Id. at 141, $277 \mathrm{P}$. at 311 (italics in original).

56. See notes $73-80$ and accompanying text infra.

57. 31 Cal. App. 3d at 58, 65, 107 Cal. Rptr. at 223, 228.

58. 13 Cal. $3 d$ at 216, 529 P.2d at 576, 118 Cal. Rptr. at 152.

59. CAL. Govt CODE $\S 65803$ (West 1968) provides: "The provisions of this chapter shall not apply to a chartered city, except to the extent that the samo may be adopted by charter or ordinance of the city." In San Diego, the court rejected a contention that the charter, by providing that the planning commission's duties were to be as prescribed by state law, had adopted the State Zoning Law. The court noted the ambiguity of the section and the general judicial policy of liberality towards the initiative. $13 \mathrm{Cal} .3 \mathrm{~d}$ at 209-10, $529 \mathrm{P} .2 \mathrm{~d}$ at $572,118 \mathrm{Cal}$. Rptr. at 148.

60. 13 Cal. $3 \mathrm{~d}$ at 216,529 P.2d at 576, $118 \mathrm{Cal}$. Rptr. at 152. 
The 1972 decision of Scott v. City of Indian Wells ${ }^{61}$ has also been cited as providing a constitutional rationale for the zoning hearing. ${ }^{62}$ The case concerned a suit brought by an owner of property just outside the city's boundaries to set aside the issuance of a use permit for a development that would adversely affect the value of his land. The municipality held a hearing on the use permit application, and gave notice of hearing to property owners within the city, but not to affected owners outside the city limits. ${ }^{63}$

The California Supreme Court, in a unanimous opinion written by the late Justice Raymond Peters, declared that the fourteenth amendment was violated by the failure to give notice:

‘C]ommon sense and wise public policy . . . require an opportunity for propenty owners to be heard before ordinances which substantially affect their property rights are adopted. ... [citation omitted]. Indeed, the due process clause of the Fourteenth Amendment requires 'at a minimum ... that deprivation of life, liberty or property by adjudication be preceded by notice and opportunity for learing. ...' (Mullane v. Central Hanover Co. (1950) 339 U.S. 306, 313 . . . . Zoning does not deprive an adjacent landowner of his property, but it is clear that the individual's interest in his property is often affected by local land use controls, and the 'root requirement' of the due process clause is 'that an individual be given an opportunity for a hearing before he is deprived of any significant property interest, except for extraordinary situations where some valid governmental interest ... justifies postponing the hearing until after the event. ...' (Boddie v. Connecticut (1971) 401 U.S. 371, 379). ${ }^{64}$

On the basis of this statement the appeals courts in Taschner, People's Lobby and Livermore concluded that the initiative could not be used to enact any ordinance which deprived a property owner of a significant property interest. ${ }^{65}$ The Taschner opinion sought to distinguish prior cases allowing the initiative's use in zoning on the basis that

61. 6 Cal. 3d 541, 492 P.2d 1137, 99 Cal. Rptr. 745 (1972).

62. San Diego Building Contractors v. City Council, 13 Cal. $3 \mathrm{~d}$ at 221,529 P.2d at $574,118 \mathrm{Cal}$. Rptr. at 150 (dissenting opinion); Associated Home Builders v. City of Livermore, 116 Cal. Rptr. 326, 330 (1st Dist. 1974), hearing granted, Nov. 8, 1974; Taschner v. City Council, 31 Cal. App. 2d 48, 65-66, 107 Cal. Rptr. 214, 228-29 (4th Dist. 1973); People's Lobby, Inc. v. Board of Supervisors, 30 Cal. App. 3d 869, 873, 106 Cal. Rptr. 666, 669-70 (1st Dist. 1973).

63. 6 Cal. 3d at 544, 492 P.2d at 1138, 99 Cal. Rptr. at 746.

64. Id. at $548-49,492$ P.2d at $1141-42,99 \mathrm{Cal}$. Rptr. at $749-50$ (emphasis in original).

65. Associated Home Builders v. City of Livermore, 116 Cal. Rptr. 326, 331 (1st Dist. 1974), hearing granted, November 8, 1974; Taschner v. City Council, 31 Cal. App. 3d 48, 67, 107 Cal. Rptr. 214, 230 (4th Dist. 1973); People's Lobby, Inc. v. Board of Supervisors, 30 Cal. App. 3d 869, 873, 106 Cal. Rptr. 666, 669-70 (1st Dist. 1973). 
a significant interference with land use did not exist in those cases. ${ }^{00}$ However, Scott should not be read for the proposition that all zoning decisions require advance notice and hearing. As discussed infra, ${ }^{67}$ Scott is properly limited to zoning decisions which are adjudicatory, rather than legislative, in nature.

The appeals court decisions nullifying initiative zoning also cited the California Supreme Court's decision in City of Escondido v. Desert Outdoor Advertising ${ }^{68}$ as providing a constitutional rationale for the zoning hearing. That case concerned an attempt by a general law city to enforce an ordinance regulating placement of billboards and signs along the city's highways. Defendants contended that the regulation was of the type specified in the State Zoning Law as requiring notice and a public hearing before passage; since such a hearing had not been held, defendants argued, the regulation was void. ${ }^{69}$ The court construed California Government Code section 38774, which grants general law cities the power to regulate billboards, as authorizing the city's ordinance and concluded that the section's specific grant of authority exeinpted billboard regulation from the procedural requireinents of the State Zoning Law, thus allowing the ordinance to be enacted without public hearing. ${ }^{70}$ The unanimous opinion by Justice Burke then declared:

We emphasize that ordinarily municipalities must follow statutory or charter zoning procedures strictly whenever they propose a substantial interference with land use, for such procedures are constitutionally mandated to insure that private property owners receive due process of law. ${ }^{71}$

This statement, labelled a gratuitous dictum by the majority in San Diego ${ }^{72}$ was supported by citations to the passages of Scott and Hurst quoted above, and did not appear to extend the principles enunciated in those cases.

66. 31 Cal. App. 3d at 67-69, 107 Cal. Rptr. at 229-31. A freeze on zoning changes or construction would appear to be an example, in the Taschner court's view, of a zoning measure which did not signifieantly interfere with land use. Thus the same justice who wrote Taschner delivered an opinion declaring that the temporary restraint on coastal construction promulgated by the California Coastal Zone Conservation Act, enacted by initiative, was not a violation of procedural due process rights of property owners. CREED v. California Coastal Zone Conservation Commission, 43 Cal. App. 3d 306, 312-19, 118 Cal. Rptr. 315, 320-23 (4th Dist. 1974). It is not clear, however, that an ordinance which regulates building height, as in Taschner, is a more significant interference than an ordinance prohibiting eonstruction, even if the latter is only temporary.

67. See notes $94-97$ and accompanying text infra. (1973).

68. 8 Cal. 3d 785, 505 P.2d 1012, 106 Cal. Rptr. 172, cert. denied, 414 U.S. 828

69. Id. at 788, 505 P.2d at 1014,106 Cal. Rptr. at 174.

70. Id. at 789-90, 505 P.2d at 1015, $106 \mathrm{Cal}$. Rptr. at 174.

71. Id. at 790, 505 P.2d at 1016, 106 Cal. Rptr. at 176.

72. 13 Cal. $3 \mathrm{~d}$ at 216 n.6, 529 P.2d at 577 n.6, 118 Cal. Rptr. at 153 n.6. 


\section{San Diego: Adjudication v. Legislation}

In San Diego, the California Supreme Court, in upholding an initiative zoning measure, rejected the dicta of Scott and Escondido as ignoring the distinction between adjudicative action-for which a trialtype hearing in advance of the decision is required-and legislative action, for which no special procedure is constitutionally compelled. ${ }^{73}$ The action at issue in San Diego was deemed to be of the latter type. The court based its decision largely upon the United States Supreme Court's 1915 ruling in Bi-Metallic Investment Co. v. State Board of Equalization. ${ }^{74}$ Bi-Metallic arose from the Colorado state board of equalization's decision to increase the percentage of market value to be considered in calculating property taxes; the decision had the effect of a sharp tax increase. Property owners claimed that a prior hearing was constitutionally compelled. Justice Holmes, writing for a unanimous court, characterized the plaintiffs as claiming that "all individuals have a constitutional right to be heard before a matter can be decided in which all are equally concerned." He dismissed this contention, writing:

Where a rule of conduct applies to more than a few people it is impracticable that every one should have a direct voice in its adoption. The Constitution does not require all public acts to be done in town meeting or an assembly of the whole. General statutes within the state power are passed that affect the person or property of individuals, sometimes to the point of ruin, without giving them a chance to be heard. Their rights are protected in the only way that they can be in a complex society, by their power, immediate or renote, over those who make the rule ... It appears to us that to put the question is to answer it. There must be an end to individual argument in such Inatters if government is to go on. ${ }^{75}$

The ordinance involved in San Diego, a limitation on building height within a large coastal zone, is analogous to the governmental decision upheld in Bi-Metallic; both substantially affected large portions of the community. The dissenting justices in San Diego, however, sought to distinguish $B i$-Metallic on the basis that zoning ordinances uniquely affect property values. ${ }^{76}$ In support, the dissent cited a series of cases declaring that a prior hearing was necessary to the constitutionality of a zoning regulation. ${ }^{77}$ As pointed out earkier, inost statements of this kind are supported by little reasoning and are often merely dicta. ${ }^{78}$ More

73. Id. at $211-17,529 \mathrm{P} .2 \mathrm{~d}$ at $573-78,118 \mathrm{Cal}$. Rptr. at 149-54.

74. 239 U.S. 441 (1915).

75. Id. at 445 .

76. 13 Cal. $3 d$ at $219-20,529$ P.2d at 579-80, 118 Cal. Rptr. at 155-56.

77. Id. at 220, 222, 529 P.2d at 580-81, 118 Cal. Rptr. at 156.

78. See notes $46-47$ and accompanying text supra. The dissent cited cases both from California and other jurisdictions. As discussed earlier, the statements of California 
fundamentally, the dissent's distinction appears factually weak; virtually every kind of social and economic regulation, including the tax increase caused by the ordinance upheld in Bi-Metallic, may seriously affect property values. ${ }^{79}$ Nor does the dissent explain why only real property rights should be accorded such procedural protection. ${ }^{80}$ Further, as stated in Bi-Metallic, groups have, for constitutional purposes, adequate alternative means of protecting themselves in the political process. For example, legislators, fearful of adverse political consequences, may respond to informal lobbying or written petition. ${ }^{81}$ While a requirement of oral hearings prior to legislation may allow greater protection to property owners, its benefits are outweighed by the delay and burden on government.

But, despite Bi-Metallic, the normal legislative process is not constitutionally sufficient when the decision to be made is "adjudicative" in nature. For instance, in 1908 the Supreme Court held in Londoner $v$. $D_{\text {Denver }}{ }^{22}$ that a prior oral hearing was compelled. In that case, property owners sued to set aside a special assessinent of taxes on their land to pay for local improvements. The owners had not been allowed to appear before the city council to contest the valuation placed on their property; the Court ruled that the opportumity provided by the council to submit written objections was insufficient. ${ }^{83}$ In Bi-Metallic, Holmes distinguished Londoner as concerning "a relatively swall number of persons ... who were exceptionally affected, in each case upon individual grounds. . . .".84

The adjudicative-legislative distimction has long been important in zoning as the means to determine, for example, the extent of judicial

cases that a prior hearing is required are uniformly dicta. The out-of-state cases cited in the dissent are Bell v. Studdard, 220 Ga. 785, 141 S.E.21 536 (1962) (no justification given for holding); Cugini v. Chiaradio, 96 R.I. 120, 189 A.2d 798 (1963) (dicta in decision upholding grant of zoning exception); Hart v. Bayless Investment \& Trading Co., 86 Ariz. 379, 346 P.2d 1101 (1959) (dicta in decision striking down zoning ordinance for failure to comply with statutory hearing requirements); Vandervort v. Sisters of Mercy, 19 Ohio App. 153, 117 N.E.2d 51 (1952) (dicta in decision invalidating administrative amendment of zoning ordinance).

79. On the effects of property tax rates and structures on property values and economic development, see D. NETZER, THE Economics OF THE ProperTY TAX (1966); for discussion of various reform proposals, see Alpert, Property Tax Abatement: An Incentive for Low Income Housing, 11 Harv. J. LeGIs. 1 (1973); Note, Site Value Taxation: Economic Incentives and Land Use Planning, 9 HARv. J. LEGIS. 115 (1971).

80. Cf., e.g., Goldberg v. Kelly, 397 U.S. 254; Reich, The New. Property, 73 YALE L.J. 733 (1964) (suggesting that a government benefit be regarded as property).

81. For the contention that the lack of direct accountability of administrative agencies mandates public participation in decisionmaking see Comment, Duc Process Rights of Participation in Administrative Rulemaking, 63 CALIF. L. REv. 886 (1975).

82. 210 U.S. 373 (1908).

83. Id. at 385-86.

84. 239 U.S. at 446 
review. Courts have tended to give far more deference to "legislative" decisions about zoning ordinances than to "quasi-judicial" or "administrative" decisions such as awards of use permits ${ }^{85}$ and variances. ${ }^{86}$ The decisions frequently state that the substance of a zoning ordinance will be presumed constitutional and will not be overturned unless it bears no relationship to a valid mumicipal purpose. ${ }^{87}$ Courts have also generally refused to mvestigate charges of improper legislative inotive, such as conflict of interest, stating that such an investigation would be disrespectful of a coordinate branch of government. ${ }^{88}$ One of the most extreme examples of judicial leniency towards zoning ordinances is McCarthy v. Manhattan Beach, ${ }^{89}$ where an owner of oceanfront property sued to invalidate a zoning ordinance prohibiting him from using his property for other than a beach; the owner contended that the ordinance violated substantive due process because it permitted no profitable use of the land. There was considerable evidence that the regulation was largely motivated by the city council's desire to keep the property's value low so that it could be purchased cheaply in the future. The California Supreme Court, however, upheld the ordinance, stating that it would be improper to inquire into legislative motive, ${ }^{90}$ and that the regulation could be related to a valid purpose (e.g.; preventing "immoral activi-

85. Most compreheusive zoning codes list certain uses which will be allowed only upon issuance of a use permit (sometimes also called a special permit) by an administrative officer or board. Typically, the administrative authority must find that the use will not be detrimental to the general health and safety. Such permits are often required for two general categories of uses: (1) those which may present special problems (noise, traffic, etc.) if allowed to concentrate unduly in a single zoning district (e.g., schools, churches) and (2) those which present special problems for which solutions must be devised on a case-by-case basis (e.g., airports, trailer camps). For discussion of the use permit, see D. Hagman, J. Larson, \& C. Martin, California Zoning Practice $\$ 7.64$ (1969) and R. ANDERson, AMERICAN LAW OF ZoNing $\$ 15$ (1968).

86. A variance permits a property owner to be exempted from enforcement of the zoning ordinance upon a showing of hardship to an administrative body or officer. For example of statutory criteria, see CAL. Gov'x CoDE $\$ 65906$ (West 1972). In practice, the device is often badly abused. For discussion of the variance, see D. HAGMAN, J. Larson, \& C. Martin, Calmfornia Zoning Practice \$\$ 7.15 et seq. and R. Anderson, AMRRICAN LAW OF ZONING $\$ 14.01$ et seq. (1968).

87. See, e.g., Euclid v. Ambler Realty, 272 U.S. 365, 388 (1926) (legislative judgment to be upheld if wisdom of zoning enactment is "fairly debatable"); Consolidated Rock Products Co. v. City of Los Angeles, 57 Cal. 2d 515, 370 P.2d 342, 20 Cal.' Rptr. 638, cert. denied, 371 U.S. 36 (1962); Montgomery County Council v. Pleasants, 266 Md. 462, 295 A.2d 216 (1972).

88. See, e.g., Miami Beach v. Schauer, 104 So. $2 d 129$ (Fla. App. 1958), cert. discharged, 112 So. 2d 838 (Fla. 1959), noted in 57 MicH. L. REv. 423 (1959); Coffin v. City of Lee's Summit, 357 S.W.2d 211 (Mo. App. 1962), noted in 31 U. KAN. CY. L. REv. 366 (1963). The history of the rule is traced in a non-zoning context in County of Los Angeles v. Superior Court (Burroughs), 13 Cal. 3d 721, 532 P.2d 495, 119 Cal. Rptr. 631 (1975).

89. 41 Cal. 2d 879, 264 P.2d 932 (1953), cert. denied, 348 U.S. 817 (1954).

90. Id. at $894-95,264$ P.2d at $940-41$. 
ties" under the pilings that would be necessary to support construction): ${ }^{\text {} 1}$

In comparison to zoning ordinances, awards of use permits or variances have come under increasingly vigilant judicial supervision, even where the local legislative body has made the award. For instance, in Topanga Association for A Scenic Community v. County of Los Angeles $^{22}$ the California Supreme Court required the board awarding the variance to render findings of fact so that the reviewing court could more easily determine if the statutory criteria for a variance had been inet. A growing number of decisions in other states have required that variance boards take testimony under oath and allow cross examination. ${ }^{93}$ Scott $v$. City of Indian Wells, ${ }^{94}$ frequently cited for the proposition that advance notice and hearing is necessary for a legislative zoning decision, ${ }^{95}$ is better regarded as part of the trend towards stricter scrutiny of adjudicative zoning procedure. The Scott decision required notice to affected landowners outside the city limits prior to a hearing in an adjudicative zoning action, the issuance of a use permit. ${ }^{96}$ The limitation of the court's reasoning to adjudicative proceedings is shown by its citation of cases concerning judicial, rather than legislative, action for its holding that the fourteenth amendment requires notice. ${ }^{07}$

The court in San Diego indicated that the initiative's constitutional validity in zoning might be determined by the adjudicative-legislative distinction. ${ }^{98}$ There are two possible ways this might be done. First, a

91. Id. at 890,264 P.2d at 938 . One dissenting judge commented, "I should like to think that the scheme here resorted to was beneath the honor of a self-respecting American municipahty." Id. at 900, 264 P.2d at 944.

92. 11 Cal. 3d 506, 522 P.2d 12, 113 Cal. Rptr. 836 (1974), noted in 63 Calif. L. REv. 11 (1975).

93. Somerset v. Montgomery County Bd. of App., 245 Md. 52, 225 A.2d 294 (1967); Dietrich v. District of Columbia Bd. of Zoning Adjustment, 293 A.2d 470 (Dist. Col. App. 1970). Arcaro Bros. Builders, Inc. v. Zouing Bd. of Appeals, 7 Ohio St. 32, 218 N.E.2d 179 (1966).

94. 6 Cal. 3d 541, 492 P.2d 1137, 99 Cal. Rptr. 745 (1972).

95. Associated Home Builders v. City of Livermore, 116 Cal. Rptr. 326, 330 (1st Dist. 1974), hearing granted, November 8, 1974; Taschner v. City Council, 31 Cal. App. 3d 48, 65, 107 Cal. Rptr. 214, 228 (4th Dist. 1973); People's Lobby, Inc. v. Board of Supervisors, 30 Cal. App. 3d 869, 874, 106 Cal. Rptr. 666, 669-70 (1st Dist. 1973).

96. 6 Cal. 3d at 544, 492 P.2d at 1138, 99 Cal. Rptr. at 746. The plaintiffs in Scott sought review under Code of Civil Procedure section 1094.5 (West 1972), California's administrative mandamus statute, which apphes only to adjudicatory dccisions. See W. DeEring, California AdmInistrative Mandamus $\$ 2.2$ (1967). On classification of the award of a use permit as adjudicatory in California, see Essick v. City of Los Angeles, 34 Cal. 2d 614, 213 P.2d 492 (1950); Johnston v. Board of Supervisors, 31 Cal. 2d 66, 73, 187 P.2d 686, 691 (1947).

97. Scott cited Mullane v. Ceutral Hanover Trust, 339 U.S. 306 (1950) (personal notice required in judicial settlement of trust accounts), and Boddie v. Connecticut, 401 U.S. 371 (1971) (fee requirements for commencement of divorce proceedings struck down).

98. 13 Cal. 3d at 212,529 P.2d at 574, 118 Cal. Rptr. at 150. 
court might decide that a particular zoning decision was adjudicative, thus demanding a prior hearing, and find that the initiative did not offer equivalent protections to concerned parties. ${ }^{99}$ Second, a court, after finding that the decision affected by initiative was adjudicative, might simply cite the historic rule that the initiative is limited to legislative decisions, ${ }^{100}$ and nullify any use of that device to affect an adjudicative decision. ${ }^{101}$

The use of the adjudicative-legislative distinction to decide the scope of the initiative's application to zoning presupposes that a logical line can be drawn between adjudication and legislation. This has not proven to be the case, even where the mitiative is not involved.

Some jurisdictions, including California, classify zoning actions as adjudicative or legislative according to the form of the proceeding. These decisions reason that every zoning amendment, even one which concerns only an individual parcel, should be based on considerations of communitywide policy. ${ }^{102}$ In contrast, decisions on use perunits or variances involve only the question of whether certain specified criteria (e.g., hardship) have been met.

But an adjudicative-legislative distinction based entirely on the form of the local land use action would lead to unrealistic judicial results. In the conventional zoning process, a decision on an application for a zoning ordinance amendinent rezoning a single parcel is likely to be based on the same considerations as a decision on a variance and use permit; ${ }^{103}$ in soine states, zoning ordinance and variance decisions are even decided by the same body. ${ }^{104}$ Moreover, the same policy that leads

99. Cf. id. at 221-224, 529 P.2d at 580-82, 118 Cal. Rptr. at 156-58.

100. See, e.g., Glass v. Smith, 150 Tex. 632, 244 S.W.2d 645 (1951) (dictum); Comment, The Scope of the Initiative and Referendum in California, 54 CaLIF. L. REv. 1717, 1734-38 (1966); cf., e.g., Hopping v. Council of City of Richmond, $170 \mathrm{Cal} .605$, 150 P. 977 (1915) (dictum); Durocher v. King County, 80 Wash. 2d 139, 492 P.2d 547 (1972).

101. For use of the rule to nullify an attempt to challenge a zoning decision by referendum, see West v. City of Portage, 392 Mich. 458, 221 N.W.2d 303 (1974).

102. See, e.g., Dwyer v. City Council, 200 Cal. 505, 514, 253 P. 932, 936 (1927) ("The restrictions relating to any portion of the city are an integral part of an entire scheme and should be the expression of a definite policy."); accord, City of Coral Gables v. Carmichael, 256 So. 2d 404 (3d Dist. Ct. App. Fla.), cert. discharged, 266 So. 2d 1 (Fla. 1972); cf. Topanga Ass'n for a Scenic Community v. County of Los Angeles, 11 Cal. 3d 506, 522, 522 P.2d 12, 22, 113 Cal. Rptr. 836, 846 (1974) (indicating disapproval of use of variance to decide land use policy for 28 acre parcel).

103. Cf. R. ANDERSON, AMERICAN LAW OF ZONING \$ 14.04 (1968):

While the legal distinction between a variance and an amendment is clear, the factual product of an amendment which reclassifies a sinall parcel of land is so similar to that of a variance which affects the use of a parcel of sinilar size, that the propriety of a variance which permits a use prohibited by the zoning regulations is open to question.

104. See, e.g., CAL. Gov'T CoDE $\S \S 65901,65903-04$ (West 1968) (permitting legislative body to act as appeal board on variance application). 
courts to review strictly use permit and variance grants-a fear that selective alteration of zoning classifications would destroy comprehensive land use planning ${ }^{105}$-also applies to amendments rezoning a small parcel. It would seem anomalous to allow a local legislative body to escape strict judicial scrutiny merely by characterizing all of its land use actions as zoning amendments. Not surprisimgly, therefore, the courts of many jurisidctions carefully scrutinize the substance of zoning amendments that "spot-zone" by picking out a small parcel for especially harsh or lemient treatment. ${ }^{106}$

In addition, an increasing number of jurisdictions classify hearings on a proposed zoning change for a single parcel as "adjudicative." These decisions typically reason that the rezoning hearing is primarily concerned with determining contested facts (e.g., if the sewage system would be able to accomodate the needs of a proposed apartment house) rather than with ascertaining broad policy goals. ${ }^{107}$ Therefore, these decisions conclude, procedural safeguards similar to those available in judicial proceedings, such as prohibitions against decisionmaking by persons with conflicts of interest ${ }^{108}$ and requirements that cross-examination be allowed, ${ }^{109}$ are appropriate to protect individual property owners.

These decisions have led one commentator to suggest that "legislative" zoning decisions be defined as those which prescribe a general policy applicable to an "open class" of persons, situations, or interests; adjudicative zoning decisions would be those applying the policy to specific facts. ${ }^{110}$ For instance, an ordinance setting out requirements for the zoning of a parcel as a Planned Residential Zone would be legislative, while a subsequent amendment which zoned a specific parcel as a

105. See, e.g., Topanga Ass'n for A Scenic Community v. County of Los Angeles, 11 Cal. 3d 506, 517, 522 P.2d 12, 19, 113 Cal. Rptr. 836, 843 (1974).

106. See, e.g., Bosse v. Portsmouth, 107 N.H. 523, 226 A.2d 99 (1967); Damick v. Planning \& Zoning Commission, 158 Conn. 78, 256 A.2d 428 (1969); R. ANDerson, AMERICAN LAW OF ZoNing $\$ 5.04-.08$ (1968); cf. Hamer v. Town of Ross, 59 Cal. $2 \mathrm{~d}$ 776, 782-83, 382 P.2d 75, 79, 31 Cal. Rptr. 335, 339 (1963) (public benefit must bo shown to justify imposition of one-acre lot requirement whose effect fell primarily on a single parcel).

107. See, e.g., Fasano v. Bd. of County Comm'rs, 264 Ore. 574, 507 P.2d 23 (1973); Fleming v. City of Tacoma, 81 Wash. 2d 292, 298-99, 502 P.2d 327, 331 (1972); Dillon Cos. v. City of Boulder, 183 Colo. 117, 122, 515 P.2d 627, 629-30 (1973). For commentary, see Freilich, Fasano v. Board of County Commissioners of Washington County: Is Rezoning an Administrative or Legislative Function?, 6 URBAN LAWYRR vii (1974).

108. See, e.g., Fleming v. City of Tacoma, 81 Wash. 2d 292, 502 P.2d 327 (1972).

109. See, e.g., Chrobuck v. Snohomish County, 78 Wash. 2d 884, 480 P.2d 489 (1971).

110. Comment, Zoning Amendments-The Product of Judicial or Quasi-Judicial Action, 33 OHо ST. L.J. 137 (1972). 
Planned Residential Zone after a hearing on compliance with the statutory requirements would be adjudicative. ${ }^{111}$ In effect, the amendment would be treated like a use permit or variance award; this result is logical since the decision on whether a parcel meets statutory requirements for a particular classification resembles a decision on whether a parcel meets requirements for a use permit or variance; both kinds of decisions should be treated alike for purposes of judicial review.

But the proposed definition does not clearly classify a decision, which, while applying to a specific land area, prescribes a general policy rather than apply previously promulgated criteria. An example of such a decision would be the initiative ordinance upheld in San Diego: a building height restriction, founded upon a general community desire to curb certain types of development, which applied to a specified coastal zone. ${ }^{112}$

Another proposed classification of zoning actions as adjudicative or legislative is based upon Professor Kenneth Culp Davis's distinction between "adjudicative" and "legislative" facts. ${ }^{113}$ Davis argues that, in considering the requisites of procedural due process, a court ought not attempt to classify the proceeding as adjudicative or legislative but instead should focus its inquiry on the type of facts involved in the proceeding. He contends that an oral hearing serves little purpose when legislative facts-general information about policy and broad community characteristics - are involved, since the immediate parties are unlikely to possess any special insight into these facts. In contrast, an oral hearing, along with such protections as confrontation of adverse witnesses and cross-examination, is appropriate when adjudicative facts-facts about the parties and their activities-are at issue. For instance, Davis argues, a draft registrant can present information about his eyesight far more effectively than he can about the desirability of a military eyesight requirement. ${ }^{114}$

Davis's suggested distinction has been widely adopted by the courts in determining when an oral hearing is necessary before governmental action is taken. ${ }^{115}$ However, the line between "adjudicative" and "legislative" facts is often difficult to draw. For instance, the First and Second

111. See, e.g., Fasano v. Bd. of County Comm'rs, 264 Ore. 574, 581 P.2d 26 (1973).

112. For the text of the San Diego ordinance, see 13 Cal. $3 \mathrm{~d}$ at 208 n.1, 529 P.2d at 571 n.1, 118 Cal. Rptr. at 147 n.1.

113. See, e.g., Hyson v. Montgomery County Council, $242 \mathrm{Md} .55,64,217$ A.2d 578, 584 (1967); Lorland Civic Ass'n v. DiMatteo, 10 Mich. App. 129, 135-36, 157 N.W.2d 1, 5 (1967).

114. K. Davis, Adminstrative LAW Text $\$ 7.03$ (3d ed. 1972).

115. See, e.g., SEC v. Frank, 388 F.2d 486, 491 (2d Cir. 1968); Air Line Pilots Ass'n v. Quesada, 276 F.2d 892, 896 (2d Cir. 1960) cert. denied, 366 U.S. 962 (1961). 
Circuits are divided on whether a decision to raise rents in governmentassisted low-cost housing involves "adjudicative" or "legislative" facts. ${ }^{116}$ Such a decision would seem to involve both general economic considerations and the particular experience of a given project. Another example is Powelton Civic Home Owners Association v. Department of Housing and Urban Development, ${ }^{117}$ where a Umited States district court declared that a decision to tear down homes in an urban renewal area rather than attempt rehabilitation was legislative and thus did not require an adjudicatory hearing. The court concluded that factors such as the availability of funding and the overall impact of the project constituted "general facts." 118 However, it seems clear that such adjudicatory facts as the difficulty of rehabilitating the mdividual houses and the possible hardship of relocation would be involved in making the decision. Similarly, a decision on passage of a master zoning plan for a community may involve not only general considerations about the future community welfare but also individual facts about the suitability of specific land areas for development. Several commentators have concluded that virtually any decision can be described under the Davis test as both adjudicative and legislative; ${ }^{119}$ one writer has called the Davis test "as elusive as all the other magic keys which have been offered."120

None of the approaches discussed above appears to furnish the solution to determining whether a particular zoning action is "adjudicative" or "legislative." Perhaps the entire effort to so classify zoning proceedings is mistaken. A single test should not be relied upon to determine the scope of judicial review, the extent of procedural protection necessary, and the availability of initiative. Each involves different policy decisions, and thus each should be determined independently.

\section{A Balancing Approach}

The constitutional validity of the initiative's use in zoning ought not to be determined by cliches about "adjudicative" and "legislative" proceedings, but rather by a balancing of the value of popular participation in decisionmaking against any added possibility of prejudice to property owners. This balancing approach to determining the fourteenth amendinent rights of property owners would be consistent with the United States Supreme Court's recent decisions on procedural due

116. See Langevin v. Chenango Court, Inc., 447 F.2d 296, 300 (2d Cir. 1971); Hahn v. Gottlieb, 430 F.2d 1243, 1248 (1st Cir. 1960).

117. 284 F. Supp. 809 (E.D. Pa. 1968).

118. Id. at 829-30.

119. E.g., Robinson, The Making of Administrative Policy: Another Look at Rulemaking and Adjudication and Administrative Procedure Reform, 118 U. PA. L. REv. 485, 503-04 (1970); Nathanson, Book Review, 70 Yal. L.J. 1210, 1211 (1961).

120. Nathanson, Book Review, 70 Yale L.J. 1210, 1211 (1961). 
process. In a line of cases beginning with Goldberg $v$. Kelly, ${ }^{121}$ the Court has held that the right to a hearing before deprivation of a governmental benefit is determined by weighing not only the magnitude of the property interest affected, but also the usefulness of a hearing in the decisionmaking process and the burden to the government of providing a hearing. Considerations such as the type of facts involved thus are weighed in making the determination, but are not dispositive. ${ }^{122}$

Under this balancing test, the validity of the initiative's use in zoning should be upheld. The initiative process contains adequate safeguards against arbitrary decisionmaking; the open process of a political campaign is likely to reveal to the voters adequate information upon which to make an intelligent decision. Even if some prejudice may be suffered by individual property owners, courts should consider the unique educational and participatory values represented by the initiative. Moreover, the protection of property owners may be accomplished by means other than categorically prohibiting the initiative's use. Courts should consider the possibility of heightened judicial scrutiny of the substance of initiative measures which seem to focus on an individual parcel rather than on broad community objectives; this type of review would be in accord with the close judicial scrutiny of "spot-zoning" discussed above. Courts concerned about forcing property owners to wage both a pohtical campaign and a subsequent legal challenge may wish to consider relaxing the traditional judicial reluctance to rule on the validity of an initiative measure prior to passage. ${ }^{123}$

II

\section{The Administrative-Legislative Distinction}

The administrative-legislative distinction, predicated on state law

121. 397 U.S. 254 (1970).

122. One useful criterion in decisionmaking would be the extent to which adjudication is suited to effective decisionmaking in zoning cases. Lon Fuller, for instance, has suggested that adjudication is useful only when the parties can isolate particular issuese.g., if stated criteria have been met-for argument. This isolation, he argues, is impossible in "polycentric" decisions-those involving design of allocation of scarce resources where the decision on any individual elenent depends on the disposition of others. This type of "polycentricity" can often occur in zoning. For discussion of the concept, see Fuller, Adjudication and the Rule of Law, 1960 Proc. AM. Soc'Y INT'L L. 1, 3-5 (1960); Fuller, Collective Bargaining and the Arbitrator, 1963 WIsc. L. Rev. 3, 3034 (1963); Henderson, Judicial Review of Manufacturers Conscious Design Choices: The Limits of Adjudication, 73 CoLum. L. Rev. 1531, 1534-39 (1973).

123. Courts have regarded determination of an initiative's validity prior to enactment as a matter of equitable discretion. Comment, The Scope of the Initiative and Referendum in California, 54 CALIF. L. REv. 1717, 1726-29 (1966); see Harnett v. County of Sacramento, 195 Cal. 676, 682-83, 235 P. 445, 448 (1925); Lewis v. Jordan, Sac. No. 7549 (Cal. Sup. Ct. June 3, 1964) (mein. decision), reproduced in Clancy \& Nemerovski, Some Legal Aspects of Proposition Fourteen, 16 Hastings L.J. 3 (1964); State ex rel. O'Connell v. Kramer, 73 Wash. 2d 85, 436 P.2d 786 (1968). 
rather than the federal constitution, is another basis on which the validity of initiative and referendum measures have been evaluated. The administrative-legislative distinction excludes from the ballot measures which concern the execution of existing policy, rather than the establishment of new policy. ${ }^{124}$ This distinction should not be confused with the adjudicative-legislative distinction described above, although at least one court has done so. ${ }^{125}$ The adjudicative-legislative distinction is designed to protect the procedural rights of individuals, while the administrative-legislative doctrine attempts to protect government from "unwarranted harassment" or "disruption" by the initiative and referendum process. ${ }^{126}$

Some courts have also explained the distinction as necessary to carry out the intent of constitutional and statutory provisions establishing the initiative and referendum; these provisions typically refer to the people's power to make "laws" or "legislation." This wording is said to bar by inplication non-legislative "administrative" measures. ${ }^{127}$ It has proven impossible to draw clear-cut lines between "administration" and "legislation," ${ }^{28}$ and one prominent commentator has called for abandonment of the distinction as unworkable. ${ }^{120}$

The referendum is especially vulnerable to the administrative-legislative distinction because it suspends operations of the challenged ordinance until an election can be held and thus creates an opportunity for "disruption." However, im at least one case, the administrative-legislative distinction has been used to block voter consideration of an initiative measure. ${ }^{130}$

124. See, e.g., Kelly v. John, 162 Neb. 319, 75 N.W.2d 713 (1956); Durocher v. King County, 80 Wash. 2d 139, 152-53, 492 P.2d 547, 555 (1972); 5 E. McQuillin, MUNICIPAL CoRPoRatIons $\$ 16.55$ (3d rev. ed. 1968). While Kelly is frequently citcd for the proposition, its authoritative value has been diminisled by the Nebraska Supreme Court in Hoover v. Carpenter, 188 Neb. 405,197 N.W.2d 11 (1972).

125. See West v. City of Portage, 392 Mich. 458, 221 N.W.2d 303 (1974).

126. See Lincoln Property Co. No. 41 v. Law, 45 Cal. App. 3d 230, 234, 119 Cal. Rptr. 292, 294 (1st Dist. 1975); Forman v. Eagle Thrifty Drugs \& Markets Inc., 89 Nev. 533, 537-38, 516 P.2d 1234, 1236-37 (1973); Hopping v. Council of City of Richmond, 170 Cal. 605, 611, 150 P. 977, 979 (1915); Dooling v. City Council, 242 Mass. 599, 602, 136 N.E. 616, 617 (1922); Note, Limitations on Initiative and Referendum, 3 STAN. L. Rev. 497, 504 (1951).

127. See, e.g., West v. City of Portage, 392 Mich. 458, 221 N.W.2d 303 (1974). Examples of such constitutional provisions include ARIz. Const. art. IV, pt. I, \& 1; CaL. CoNST. art. IV, $\$ \S 1,22-23 ;$ Mich. CoNST. art. II, $\$ 9$.

128. See Whitehead v. H and C Development Corp., 204 Va. 144, 129 S.E.2d 691 (1963); Comment, The Scope of the Initiative and Referendum in California, 54 Calir. L. Rev. 1717, 1735 (1966).

129. C. Antirau, Municipal Corporation LaW $\$ 4.34$ (rev. 1975).

130. One commentator has suggested that the doctrine may not be applicable to the initiative. Comment, The Scope of the Initiative and Referendum in California, 54 Calif. L. Rev. 1717, 1736 (1966). However, the Washington Supreme Court recently 
The recent California decision of Lincoln Property Co. No. 41 v. $L a w^{131}$ illustrates the doctrine. A proposal for private construction was approved by the city council, subject to later submission by the developer of a more detailed plan. The second plan was approved by the city council several months later. A group of citizens gathered the necessary signatures to force a referendum on the detailed plan. Although generally zoning measures may be challenged by referendum in Califorma, the developer successfully brought suit to enjoin the election. ${ }^{132}$ The district court of appeal concluded that approval of the detailed plan was an "administrative" act because it merely furthered the policy of allowing the construction. The court noted, however, that referenda have been permitted when the detailed plan substantially departed from that originally approved..$^{133}$

The Lincoln decision is questionable in that no specific injury to the city or the developer was shown to have resulted from the decision of the project's opponents to refrain from circulating referendum petitions until approval of the detailed plan. Prejudice to the developer in such cases can be prevented without use of the administrative-legislative distinction; the courts have generally refused to allow a legislative body to revoke a building permit which has been substantially rehed upon in good faith. ${ }^{134}$ Use of this test in referendum zoning situations would focus attention on the facts of the specific case rather than the vagne administrative-legislative distinction.

It can be argued that the rule in Lincoln is necessary to prevent opponents of a project from gaining extra time-by deferring their challenge until the action on the detailed plan-in which to gather support and thus evade the rigid time limits on filing referendum petitions. ${ }^{135}$ However, even under the decision in Lincoln, opponents

removed from a municipal ballot a measure canceling construction of a stadium; since the county had already exercised an option to purchase land and entered into various construction contracts, the court declared that the matter was "administrative". Ruano v. Spellman, 81 Wash. 2d 520, 505 P.2d 447 (1973).

131. 45 Cal. App. 2d 230, 119 Cal. Rptr. 292 (1st Dist. 1975). The California Supreme Court denied a hearing of the case on April 16, 1975.

132. Id. at 231, 119 Cal. Rptr. at 293.

133. Id. at 234-36, $119 \mathrm{Cal}$. Rptr. at 294-96; see Wheelright v. County of Marin, 2 Cal. 3d 437, 448, 467 P.2d 537, 542, 85 Cal. Rptr. 809, 814, appeal dismissed, 400 U.S. 807 (1970); Millbrae Ass'n for Residential Survival v. City of Millbrae, 262 Cal. App. 2d 222, 69 Cal. Rptr. 251 (1st Dist. 1968).

134. See, e.g., Russian Hill Improvement Ass'n v. Board of Permit Appeals, 66 Cal. 2d 34, 423 P.2d 824, 56 Cal. Rptr. 672 (1967); A. Ferland \& Sons, Inc. v. Zoning Board of Review, 105 R.I. 275, 251 A.2d 536 (1969); Twin Rocks Watesco Defense Committee v. Sheets, 15 Ore. App. 445, 516 P.2d 472 (1973).

135. Typically, referendum petitions bearing the proper number of signatures must be submitted within 30 days of the passage of the protested ordinance. See, e.g., ARIz. REv. StaT. \$ 19-142 (West 1967); CAL. Elec. Code $\$ 4051$ (West Supp. 1974). 
could have circulated an initiative petition to repeal the original approval of the project. ${ }^{136}$ Such a petition would not have been subject to the time limits on referendum petitions.

The courts of several other jurisdictions have gone farther than Lincoln by holding that any zoning change by a locality, whether by an amendment of the zoning ordinance or issuance of a special permit, is an administrative act not subject to referendum. ${ }^{137}$ Unlike Lincoln, such decisions do not merely restrict the time at which a referendum can be held, but rather prevent any referendum on the change.

These decisions customarily assert that the essential policy choice was the locality's decision to zone the city, and that subsequent changes in zoning are designed merely to effectuate the origimal zoning plan or to adjust the plan to changed conditions. ${ }^{138}$ Under this view, zoning is regarded as an end in itself. Rather, zoning should be seen as a means to accomplish any of a range of possible cominunity objectives. ${ }^{130}$ As community beliefs and goals change, a locality may wish to revise the objectives of its zoning plan. ${ }^{140} \mathrm{~A}$ referendum campaign against a change in zoning, even when the change is in accord with the original zoning plan, should be regarded by the courts as an attempt to prescribe new community policy, and thus as legislative action. ${ }^{141}$

136. State ex rel. Sharpe v. Hitt, 155 Ohio St. 529, 44 Ohio Op. 489, 99 N.E.2d 659 (1951); Duran v. Cassidy, 28 Cal. App. 574, 582, 104 Cal. Rptr. 793, 799 (5th Dist. 1972); but cf. Myers v. City Council, 241 Cal. App. 2d 237, 243, 50 Cal. Rptr. 402, 406 (2d Dist. 1966) (initiative not available to repeal a tax ordinance which was exempt from referendum under California Constitution).

137. See, e.g., West v. City of Portage, 392 Mich. 458, 221 N.W.2d 303 (1974); Durocher v. King County, 80 Wash. 2d 139, 492 P.2d 547 (1972); Bird v. Sorenson, 16 Utah 2d 1, 394 P.2d 808 (1964).

138. See Bird v. Sorensou, 16 Utah 2d 1, 2, 394 P.2d 808 (1964); Kelley v. John, 162 Neb. 319, 323-24, 75 N.W.2d 713, 716 (1956).

139. See, e.g., R. BABCOCK, The ZONING GAME 124-25 (1966):

Zoning needs no purposes of its own. Zoning is no longer a "movement" like the Single Tax or Prohibition; zoning is a process. It is that part of the political technique through which the use of private land is regulated. When zoning is thought of as a part of the governmental process it is obvious that it cau have no inherent principles separate from the goals which each person chooses to ascribe to the political process as a whole.

Cf. K. Davis, ADMTnISTRative LAW Text $\$ 1.03$ (1970): "The admiuistrative process is a governmental tool. It is no more conservative or liberal than the elevator in the Senate Office Building."

140. For instance, the original zoning plan of Berkeley, California, passed in the 1920 's, projected a population ceiling of 800,000 ; this was amended in the 1950's to reduce the ceiling to 180,000. T.J. KENT, THE URBAN Guneral PLAN 114-15 (1964).

141. Thus a number of courts have rejected the view that zoning amendments are administrative. See, e.g., Denney v. City of Duluth, 295 Minn. 22, 202 N.W.2d 892 (1972); City of Ft. Collins v. Dooney, 178 Colo. 25, 496 P.2d 316 (1972); City of Coral Gables v. Carmichael, 256 So. 2d 404 (3rd Dist. Ct. App. Fla.), cert. discharged, 266 So. $2 \mathrm{~d} 1$ (Fla. 1972). There is disagreenent among commentators on which holding constitutes the majority rule. See 1 A. Rathkopf, The Law of Zoning \& Planning 27- 
The decisions labeling zoning changes as administrative have also reasoned that the referendum's use to challenge individual zoning decisions would tend to destroy the comprehensiveness of the zoning plan. It is asserted that uniformity within zoning districts might be disrupted, ${ }^{142}$ or that essential uses might be barred from the city. ${ }^{143}$ Yet the solution for arbitrary decisionmaking in zoning by the people would seem to be the same as for poor decisionmaking by other zoning bodies: careful judicial review of zoning decisions which are not reasonably related to the public welfare. There is presently little evidence that zoning by election is apt to be less responsible than zoning through the conventional zoning process; indeed, there is ample documentation of the deficiencies of city councils and other local agencies in zoning matters. ${ }^{144}$ The openness of a political campaign could well result in better zoning decisions than those reached by zoning boards and city councils.

The administrative-legislative distinction thus appears to be an inappropriate rationale for excluding decisions on zoning changes from the electoral process. Zoning decisions should be regarded as declarations of policy rather than implementation of previously adopted decisions.

\section{III}

\section{Delegation of Legislative Power}

The use of the imitiative and referendum in zoning has also been attacked as an improper delegation of legislative power which violates fourteenth amendinent due process rights of property owners. This view was apparently adopted as to the initiative im the 1968 decision of City of Scottsdale v. Superior Court, ${ }^{145}$ where the Arizona Supreme Court, in nullifying an initiative zoning measure, cited without elaboration the United States Supreme Court's decisions in Eubank v. City of

31 (3d ed. 1974) (majority rule that amendment is administrative); C. ANTIEAU, MUNICIPAL CORPORATIONS $\$ 4.34$ (rev. ed. 1975) (Majority rule that amendment is legislative).

142. Kelly v. John, 162 Neb. 319, 323-24, 75 N.W.2d 713, 716 (1956); Township of Sparta v. Spillane, 125 N.J. Super. 519, 526, 312 A.2d 154, 157 (Super. Ct. App. Div. 1973), cert. denied, 64 N.J.493, 317 A.2d 706 (1974).

143. Elkind v. City of New Rochelle, 5 Misc. 2d 296, 301, 163 N.Y.S.2d 870, 87677 (1957), aff'd 5 N.Y.2d 836, 155 N.E.2d 404, 181 N.Y.S.2d 509 (1958).

144. For instance, administrative boards which decide on variance and use permit applications have been scathingly criticized for procedural laxness and disregard of statutory criteria. See Babcock, The Unhappy State of Zoning Administration in Illinois, 26 U. CHI. L. REv. 509 (1959); Dukeminier \& Stapleton, The Zoning Board of Adjustment; A Case Study in Misrule, $50 \mathrm{KY}$. L.J. 273 (1962); Comment, Zoning: Variance Administration in Alameda County, 50 CALIF. L. REv. 101 (1962); Comment, Variance Administration in Indiana-Problems and Remedies, 48 InD. L.J. 240 (1973). 145. 103 Ariz. 204, 207-08, 439 P.2d 290, 293-94 (1968). 
Richmond $d^{146}$ and Washington ex rel. Seattle Title \& Trust Co. v. Roberge. ${ }^{147}$ These rather dated decisions, along with Cusack Co. v. City of Chicago, ${ }^{148}$ are frequently cited for the proposition that property owners may not be given the power to prohibit a reasonable use of a neighbor's land, but may be empowered to waive a preexisting reasonable restriction. ${ }^{149}$ Thus the Court in Roberge struck down a city ordinance requiring permission of the owners of two-thirds of the property within 400 feet of a proposed orphanage or old-age home; the Court reasoned that no evidence had been presented to demonstrate that the proposed use was a nuisance. ${ }^{150}$ The Arizona court apparently reasoned that these decisions proscribed on constitutional grounds any direct citizen participation in land use decisions.

The Eubank line of cases was also cited in Forest City Enterprises, Inc. v. Village of Eastlake, ${ }^{151}$ a recent Ohio Supreine Court decision striking down a suburban charter provision compelling a citywide popular vote on each zoning change. This type of mandatory referendum differs from the permissive referenda provisions upon which this Comment focuses; the latter take place only after submission of a required number of signatures by citizens protesting a specific city action. ${ }^{162}$ Indeed, in its decision the Ohio court sought to distinguish the state's long-standing policy of allowing referenda challenging zoning changes; ${ }^{153}$ the mandatory provision, the court indicated, posed special dangers of arbitrary citizen action. ${ }^{154}$ Because of the court's failure to explain its reasoning on this point, Forest City may possibly be extended by other state courts to ban all use of the initiative and referenduin in zoning.

The vitality of Eubank and its progeny is questionable. Since the 1930's, the Supreme Court has greatly hiberalized delegation law, leading Professor Davis to suggest that "no responsible delegation is likely to be held unconstitutional." ${ }^{155}$ Indeed, in Currin v. Wallace, ${ }^{150}$ the Court

146. 226 U.S. 137 (1912).

147. 278 U.S. 116 (1928).

148. 242 U.S. 526 (1917).

149. See, e.g., Forest City Enterprises, Inc. v. Village of Eastlake, 41 Ohio St. 2d 187, 327 N.E.2d 740, cert. granted, 44 U.S.L.W. 3222 (U.S. October 14, 1975) (No. 741563); cf. Myers v. Fortunato, 12 Del. Ch. 374, 375, 110 A. 847, 878 (Del., 1925).

150. 278 U.S. at 122.

151. 41 Ohio St. 2d 187, 327 N.E.2d 740, cert. granted, 44 U.S.L.W. 3222 (U.S. October 14, 1975) (No. 74-1563).

152. See note 2 supra.

153. Ohio courts have tacitly acquiesced in the use of the initiative in zoning. See Storegard v. Board of Elections, 22 Ohio Misc. 5, 255 N.E.2d 880 (C.P.), aff'd, No. 30012 (Ohio Ct. App. 1969); Russell v. Linton, 67 Ohio L. Abs. 132, 115 N.E.2d 429 (C.P. 1969).

154. 41 Ohio St. $2 d$ at 196,327 N.E.2d at 746.

155. K. Davis, ADMINISTRATIVE LAW TEXT $\$ 2.01$ (3d ed. 1972).

156. 306 U.S. 1 (1939). 
upheld a statutory provision which, like that invalidated in Eubank, provided for the imposition of governmental regulation subject to affirmative vote of private parties. ${ }^{15 \tau}$ Without citing Eubank, the Court characterized the consent requirement as a permissible condition precedent on the operation of the legislation. ${ }^{158}$ Subsequently, the Court approved a similar consent requirement in United States $v$. Rock Royal Co-op, ${ }^{159}$ noting that if Congress could validly enact the underlying regulation, it could permissibly condition the regulation upon private consent. ${ }^{160}$

The Eubank line of cases, however, still remains good law in many states. A number of courts have struck down zoning measures which delegate power to private parties to veto non-obnoxious uses on the basis that these delegations allow arbitrary and capricious citizen action. ${ }^{161}$ But, as discussed below, the applicability of these decisions to the imitiative and referendum process is doubtful.

In several states, such as Arizona ${ }^{162}$ and California, ${ }^{163}$ the imitiative and referendum powers are expressly reserved in the state constitution to the people. These states regard political power as originating in the people, ${ }^{164}$ who have largely delegated their power to the legislature but have retained the imitiative and referendum for their own use in directly enacting laws. In no sense can the imitiative and referendum be described in these states as a delegation of power by the legislature.

Even where the initiative and referendum power are legislatively created, and thus describable as a delegation of power by the legislature, the Eubank line of cases is inapposite. The exercise of a veto power by a handful of property owners, perhaps notivated by personal economic interest, would not seem equivalent to a citywide vote by citizens who collectively probably have no more pecuniary interest in the matter than the locality's zoming officials. ${ }^{165}$

157. The Tobacco Inspection Act of August 23, 1935, § 5, 49 Stat. 731, whose constitutionality was upheld in Cummins, provided for government regulation and inspection of tobacco if a particular market was specially designated by affirmative vote of two-thirds of the growers. 306 U.S. at 6. The measure invalidated in Eubank mandated establishment of a street line upon petition of owners of two-thirds of the abutting property. 226 U.S. at 141.

158. 306 U.S. at 15-16, citing Hampton \& Co. v. United States, 276 U.S. 394, 407 (1928).

159. 307 U.S. 533 (1939).

160. Id. at 577-78.

161. See, e.g., Marta v. Sullivan, - Del. —, 248 A.2d 608 (1968); Koch v. Zoning Bd. of Appeals, 54 Misc. 2d 1090, 284 N.Y.S.2d 177 (Sup. Ct., 1967); cf. Bashant v. Walter, 78 Misc. 2d 64, 355 N.Y.S.2d 39 (Sup. Ct., 1974).

162. ARIz. CoNST. art. IV, pt. $1, \S 1$ (West 1966).

163. CAL. ConsT. art. IV, $\$ 1$ (West 1970).

164. ARIZ. Const. art. I, $\$ 2$ (West 1966) and CAL. Const. art. I, $\$ 26$ (West Supp. 1975) provide that "[A]ll political power is inherent in the people. . . ."

165. See Southern Alameda Spanish Speaking Organization v. Umion City, 424 F.2d 
Moreover, the use of delegation doctrines against thc initiative and referendum seems only to represent a revival of the argument, often heard at the turn of the century, that the initiative and referendum violate the constitutional guarantee of a republican form of government. ${ }^{166}$ Some states rejected this contention on the merits. ${ }^{107}$ The Supreme Court held that the validity of the mitiative represented a nonjusticiable political question. ${ }^{168}$ The Supreme Court has disregarded the Eubank line of cases in decisions considering the constitutionality of initiative legislation ${ }^{169}$ and compulsory referenda. ${ }^{170}$ In James $v$. Valtier$r a,{ }^{171}$ the Court upheld a provision of the California constitution requiring a local referendum before construction of low-income liousing. The Court rejected the contention that the referendum requirement violated equal protection because of its applicability only to government-sponsored housing for the poor and, by way of dictum, voiced approval of allowing the people a direct role in lawmaking. ${ }^{172}$ No mention was made, either in the opinion or in the extensive and numerous briefs, of legislative delegation.

Since certiorari has been granted in Forest City, the Court will have another opportunity to express its views on the Eubank line of cases. It appears doubtful, however, that the non-delegation doctrine furnishes a basis for holding the initiative and referendum's application to land use unconstitutional.

\section{IV}

\section{Statutory Challenges to Zoning by Initiative}

The majority of cases striking down the initiative's use in zoning have relied upon the inconsistency of the initiative process with procedural requirements mandated by state law or local cliarter for the

291, 294 (9th Cir. 1970), aff'g 314 F. Supp. 967 (N.D. Calif.):

A referendum, however, is far more than an expression of ambiguously fouuded neighborhood preference. It is the city itself legislating through its voters - and exercise by the voters of their traditional right through direct legislation to override the views of their elected representatives as to what serves the public interest. . . . This question lay at the heart of the proposition put to the voters. That some voters individually may have failed to meet their responsibilities as legislators to vote wisely and unselfishly cannot alter the result.

166. See E. Pirlsbury, Initiative Legislation Unconstitutional (1908) (originally the Brief for Plaintiff in Error in Pacific States Telephone \& Telegraph Co. v. Oregon, 223 U.S. 118 (1912)).

167. See, e.g., In re Pfalfer, 150 Cal. 71, 88 P. 270 (1906).

168. Pacific State Telephone \& Telegraph Co. v. Oregon, 223 U.S. 118 (1912).

169. See Reitman v. Mulkey, 387 U.S. 369 (1966); Lucas v. Forty-Fourth General Assembly, 377 U.S. 713 (1964).

170. See Hunter v. Erickson, 393 U.S. 385 (1969).

171. 402 U.S. 137 (1971).

172. Id. at $142-43$. 
passage of zoning measures. ${ }^{173}$ These decisions typically reason as follows: (a) the scope of the local initiative and referendum power can be no greater than the local legislative body's power; (b) state laws or city charter regulations governing procedure limit the local body's zoning power; (c) since the local legislature cannot pass zoning laws without complying with these procedural restrictions, the people's power is similarly limited; (d) the initiative process is "hopelessly inconsistent" with procedural requirements ${ }^{174}$ - for instance, no public hearing is held either before an advisory planning commission or the ultimate decisionmaking body; ${ }^{175}$ (e) because of the initiative's failure to encompass these steps, it may not be used to enact zoning legislation. The last two steps of this reasoning have not been used to nullify the referendum's use to challenge a zoning ordinance enacted by the legislative body, since procedural steps were followed in enacting the challenged ordinance. $^{176}$

\section{A. State Constitutional Provisions}

The analysis outlined above has been followed by courts even in states whose constitutions specifically guarantee the local power of initiative. ${ }^{177}$ Such guarantees are difficult to harınonize with the state legislature's broad power to prescribe the form and jurisdiction of local government-for instance, in Califorma, the state constitution permits the legislature to pre-empt charter city regulation of non-mumicipal affairs, ${ }^{178}$ and to pre-enupt general law cities on any nuatter. ${ }^{179}$ A literal

173. See, e.g., Hurst v. City of Burlingame, 207 Cal. 134, 277 P. 308 (1929) (probably the leading case on this point). Other cases include Korash v. City of Livonia, 388 Mich. 737, 202 N.W.2d 803 (1972); City of Scottsdale v. Superior Court, 103 Ariz. 204, 207-08, 439 P.2d 290, 293 (1968); State ex rel. Powers v. Donohue, 368 S.W.2d 432 (Mo. 1963); Dewey v. Doxey-Laytou Realty, 3 Utah 2d 1, 277 P.2d 805 (1954); Smith v. Township of Livingston, 106 N.J. Super. 444, 256 A.2d 85 (Super. Ct., Ch. Div.), aff'd mem., 54 N.J. 525, 257 A.2d 698 (1969); Hancock v. Rouse, 437 S.W.2d 1 (Tex. Civ. App. 1969).

174. Hurst v. City of Burlingame, 207 Cal. 134, 141, 277 P. 308, 311 (1929).

175. Such a hearing is required by section 4 of the Standard Zoning Enabling Act, supra note 33; for an example of state procedural regulation, see CAL. Gov'T CoDE $\$ \S$ 65853-57 (West Supp. 1975).

176. See West v. City of Portage, 392 Mich. 458, 472, 221 N.W.2d 303, 310 (1974); Johnston v. City of Claremont, 49 Cal. 2d 826, 836-37, 323 P.2d 71, 77 (1958). But at least one case has held the mitiative unavailable to repeal a zoning ordinance, reasoning that the notice and hearing afforded in passing the statute did uot validate a repeal accomplished without notice and hearing. State ex rel. Powers v. Donohue, 368 S.W.2d 432 (Mo. 1963). By the same reasoning, the notice and hearing given in passing the original ordinance would seem not to validate a subsequent referendum.

177. See, e.g., ARIz. Const. art. IV, pt. I, \& 1; CAL. Const. art. IV, § 1; UtaH CoNST. art. VI, $\$ 1$. For holdings in these states, see note 173, supra.

178. Bishop v. City of San Jose, 1 Cal. 3d 56, 62, 460 P.2d 137, 140, 81 Cal. Rptr. 465,469 (1969).

179. CAL. Const. art. XI, § 7; see generally Montgomery, State Pre-emption and Local Legislation, 4 SANTA ClARA LAWYER 188 (1964). 
interpretation of the initiative guarantee would bar the state legislature from withdrawing power over a subject from localities because of the diminution of initiative power which would result.

Instead, courts have adopted the opposite interpretation: that since the state legislature has power to withdraw a subject from local jurisdiction, the legislature may also prescribe proceclural requirements which prevent use of the initiative and referendum. This reasoning has been followed even where the state legislature, in enacting procedural requirements, merely used the phrase "the local legislative body shall . . ."180 and where there was httle indication that the elimination of local electoral power was necessary to the accomplishment of the legislature's pohicy goal. ${ }^{181}$ This seems to render wholly exhortatory the state constitutional provision guaranteeing the initiative and referendum.

Judicial lemiency toward diminution of initiative and referendun power through procedural requirements lias been rationalized on a number of unsatisfactory grounds. Courts frecluently say that the state legislature has in effect made an exclusive delegation of power to the local legislature, which is barred from re-delegating its power to the people. ${ }^{182}$ This argument appears to ignore the possible threat to the local initiative and referendum posed by such "exclusive delegations." In addition, the local initiative and referendun1 power is not the result of a delegation from the local legislature, but instead stenus from state constitutional provisions. ${ }^{183}$

Another justification for lemency toward the dinimution of the initiative power through procedural requirements is that the citizenry can, through the statewide power of initiative, adequately defend the local electoral power. ${ }^{184}$ This reasoning overlooks the great difficulties in organizing a statewide, as opposed to local, initiative campaign because of high signature requirements ${ }^{185}$ and the need for large sums

180. See, e.g., Geiger v. Board of Supervisors, 48 Cal. 2d 832, 838, 313 P.2d 545, 548 (1957); Simpson v. Hite, 36 Cal. 2d 125, 129-30, 222 P.2d 225, 228 (1950); cf. State ex rel. Bowen v. Kruegel, 67 Wash. 2d 673, 409 P.2d 458 (1965). But see Glass v. Smith, 150 Tex. 632, 640, 244 S.W.2d 645, 651 (1952).

181. But see Geiger v. Board of Supervisors, 48 Cal. 2d 832, 838-39, 313 P.2d 545, $548-49$ (1957).

182. See, e.g., City of Scottsdale v. Superior Court, 103 Ariz. 204, 207, 439 P.2d 290, 292 (1968); Mitchell v. Walker, 140 Cal. App. 2d 239, 295 P.2d 90 (2d Dist. 1956).

183. Cf. Sources cited at notes 162-64 supra and accompanying text contending that constitutionally-reserved mitiative power cannot be considered as a delegation of power proscribed by the fourteenth amendment.

184. See, e.g., Mervynne v. Acker, 189 Cal. App. 2d 558, 565, 11 Cal. Rptr. 340, 345 (4th Dist. 1961).

185. For instance, a statewide initiative measure in California requires the valid signatures of 5 percent of the state's registered voters. CAL. CONST. art. IV, $\$ 22$ (West Supp. 1974). One measure of the difficulty in reaching this requirement is the frequency 
of money for campaigning. ${ }^{186}$ Thus, except in the most unusual situation, it is unlikely that legislative erosion of the initiative and referendum power can be successfully challenged. ${ }^{187}$

One California decision protects the local initiative and referendum by holding that state procedural regulations cannot infringe upon the use of the initiative and referendum on subjects which are mumicipal affairs; thus, the California state legislature could not, by granting specific power to city councils to acquire park lands, prevent use of the referendum. ${ }^{188}$ This decision, however, inay apply only to charter cities, which have long had broad power over the mode of enacting municipal ordinances, ${ }^{189}$ and not to counties and general law cities. Furthernore, the decision does not guarantee use of the initiative and referendum on policy determinations made by the local legislative body on a matter of statewide concern. Thus one court removed from the ballot an initiative measure restricting placement of parking meters, reasoning that traffic regulation is a inatter of statewide concern and that therefore the grant by the state legislature of specific power to city councils to place parking meters excluded use of the initiative and referenduin on these matters. ${ }^{190}$ This decision lias the unfortunate effect of insulating local governmental institutions from popular cliallenge on a natter of public concern. ${ }^{101}$

of reports of fraud by circulators in gathering signatures. See AssEmbly COMM. ON Elections and Reapportionment, Public hraring on The IntTIative Process (1972).

186. See Casstevens, Reflections on the Initiative Process in California State Politics, 6 BuLL. INST. Gov'T Studres (1965).

187. In several instances, judicial limitations on the initiative and referendum have been successfully challenged through the political process. In the most notorious example, the California Supreme Court's holding in Housing Authority v. Superior Court, 35 Cal. 2d 550, 219 P.2d 457 (1950), that the construction of low-income housing could not be subjected to referendum, led to the passage of article XXXIV of the California Constitution mandating such a referendum. In another instance, the holding of Mervynne v. Acker, 189 Cal. App. 2d 558, 11 Cal. Rptr. 340 (4th Dist. 1961), that the placement of parking meters on city streets was not subject to referendum was revised by the passage of section 22505 of the California Vehicle Code permitting such a referendum. These instances, however, concerned situations in which the judicial limitation on initiative and referendum applies to all cities in the state. It would be more difficult to challenge initiative restrictions in the field of zoning, for which procedural regulation largely exists only for the voters of general law cities and counties, and not for the voters of the state's largest mumicipalities, charter cities.

188. Reagan v. City of Sausalito, 210 Cal. App. 2d 618, 624-25, 26 Cal. Rptr. 775, 779 (1st Dist., 1962).

189. See, e.g., Brougher v. Bd. of Public Works, 205 Cal. 426, 271 P. 487 (1928). This reading of Reagan appears to have been adopted in Fletcher v. Porter, 203 Cal. App. 2d 313, 320-21, 21 Cal. Rptr. 452, 456 (1st Dist. 1962). The latter opinion may be especially significant in that it was authored by a present justice of the California Supreine Court, and concurred in by another.

190. Mervynne v. Acker, 189 Cal. App. 2d 558, 11 Cal. Rptr. 340 (4th Dist. 1961). Cf. Alexander v. Mitchell, 119 Cal. App. 2d 816, 825, 260 P.2d 261, 265 (1st Dist. 1953).

191. Cf. Simpson v. Hite, 36 Cal. 2d 125, 129-30, 222 P.2d 225, 228 (1950), where 
It seems possible, however, to reconcile the constitutional guarantee of the initiative with the legislature's power over local entities. Courts should uphold state legislative restrictions on local initiative and referendum only where the state restriction similarly limits the power of the local legislative body. For instance, if the state legislature deprives cities of the power to regulate parking, both the city council and the locality's citizens would be limited. If, however, the legislature allows the city the substantive power, this grant would also authorize the local use of initiative and referendum. ${ }^{192}$ Under this test, the legislature could not validly prohibit use of the initiative in zoning by prescribing procedural requirements to be followed by the city's legislative body.

\section{B. Statutory Construction}

Even assuming that the legislature may validly limit the local initiative power through imposition of procedural requirements (as is certainly the case where the local initiative is of statutory, not constitutional origin), ${ }^{193}$ it is not clear that the procedural requirements already existing in the zoning area ought to be interpreted to bar local initiative.

State procedural requirements typically demand public hearings and a report by professional planners before adoption by a local legislature of a zoning amendment. ${ }^{194}$ The judiciary lias assumed that the purpose of these requirements would be circumvented if zoming were allowed through the initiative process. ${ }^{195}$

This assumption appears questionable. State legislatures, in enacting local procedural requirements, have not expressed the intention of removing zoning from the initiative power. Nor must such an intention be implied from the procedural requirements. The remarks of the drafters of the Standard Zoning Enabling Act ${ }^{196}$ indicate that procedural safeguards were intended to protect against ill-considered zoning action through advance notice to property owners, ${ }^{197}$ study by a citizen

the court refused to allow a referendum on location of a county courthouse which was being constructed pursuant to state mandate.

192. For a somewhat similar view, see Comment, The Scope of the Initiative and Referendum in California, 54 CALIF. L. Rev. 1717, 1733 (1966).

193. Examples of such states include Michigan (see generally Mich. CoMP. Laws ANN. $\S 117.4 \mathrm{i}$ (West 1967)) and New Jersey (see generally N.J. Stat. ANN. 40:69A184 et. seq. (1939)).

194. See notes 34-37 and accompanying text supra.

195. See Korash v. City of Livonia, 388 Mich. 737, 202 N.W.2d 803 (1972); Hurst v. City of Burlingame, $207 \mathrm{Cal} .134,277$ P. 308 (1929); Smith v. Township of Livingston, 106 N.J. Super. 444, 256 A.2d 85, aff'd 54 N.J. 525, 257 A.2d 698 (1969). 196. See note 38 and acconipanying text supra.

197. See, e.g., CaL. Gov't Code $\$ 65854$ (West Supp. 1975); N.J. Stat. AnN. 40:55-34 (1939); Oнго R.C. 713.12 (Page Supp. 1974). 
planning commission, ${ }^{198}$ and public hearings. ${ }^{199}$ The initiative process offers equivalent, if not identical, protections. In California, for instance, notice of intent to circulate an initiative petition must be published before signatures can be gathered, ${ }^{200}$ and the text of the initiative measure must be mailed by the jurisdiction to voters before the election along with brief written arguments by proponents and opponents of the measure. ${ }^{201}$ Even where such provisions do not exist, the adversary nature of a political campaign affords sufficient opportunity for all viewpoints to be heard.

Thus the presence of procedural safeguards in zoning enabling acts ought not to be interpreted as showing a state legislative intent to bar use of the initiative in zoning. ${ }^{202} \mathrm{~A}$ similar argnnent can be nuade with respect to acts such as the California Environinental Quality Act, ${ }^{203}$ which seeks to ensure that environmental factors are considered in governmental decisionmaking. The intent of such acts is to proniote a full discussion of relevant considerations; ${ }^{204}$ this can be accomplished as well through an initiative campaign as through preparation of a detailed environmental inipact report for study.

In one recent California case, ${ }^{205}$ defenders of the initiative's use in zoning sought to base a statutory argument on the similarities between the initiative process and the conventional zoning process. They argued that California Government Code $\S 65801,{ }^{206}$ which requires a litigant alleging procedural error in the passage of a zoning measure to show

198. See, e.g., Cal. Gov't CODE $\$ 65853$ (West Supp. 1975).

199. See, e.g., CAL. GOV'T CODE $\$ 65856$ (West Supp. 1975).

200. CaL. Elec. Code $\S \S 4002-04$ (West Supp. 1975).

201. See, e.g., CaL. Elec. CODE $\S 4017$ (West Supp. 1975).

202. The fact that state legislatures have been silent following court decisions nullifying the initiative on statutory grounds does not necessarily show that the legislature agrees with such decisions. Cf. e.g., People v. Daniels, 71 Cal. 2d 1197, 1127, 459 P.2d 225, 229, 80 Cal. Rptr. 897, 901 (1969); Cleveland v. United States, 329 U.S. 14, 23-24 (1946) (Rutledge, J., concurring).

203. CaL. Pub. Resources CoDe $\$ \$ 21000$ et seq. (West Supp. 1974).

204. Id. at $21000(\mathrm{~g}), 21001(\mathrm{~g})$; cf. Kalur v. Resor, 335 F. Supp. 1 (D.D.C. 1971); Sierra Club v. Froehlke, 359 F. Supp. 1289 (S.D. Tex. 1973); 115 CoNG. REC. 19010 (1969) (report of the Senate Committee for Interior and Insular Affairs on S. 1070, the basis for the National Environmental Policy Act of 1969).

205. Taschner v. City Council, 31 Cal. App. 3d 48, 107 Cal. Rptr. 214 (4th Dist. 1973).

206. Government Code $\$ 65801$ provides in part:

No action ... regarding any zoning matter . . . shall be ... set aside by any court ... by reason of any error ... as to any inatter ... unless after an examination of the entire case, including the evidence, the court shall be of the opinion that the error complained of was prejudicial, and that by reason of such error the party complaining ... suffered substantial injury, and that a different result would have been probable if such error had not occurred or existed.

CAL. GOV’T CODE $§ 65801$ (West Supp. 1975). 
that the error caused substantial prejudice, in effect constituted legislative approval of the initiative's deviations from the conventional process. ${ }^{207}$ The court rejected this argument, concluding that the initiative process was substantially prejudicial to property owners because of the expense of political campaigning and the absence of a staff report on the zoning cliange. ${ }^{208}$

While the court's conclusions about the initiative process are contrary to those expressed here, the decision appears correct in refusing to use section 65801 as a basis for permitting the initiative in zoning. The section does not mention the initiative, and is worded similarly to California's "substantial prejudice" provision for determining whether a criminal conviction should be overturned. ${ }^{200}$ The latter section has been interpreted to require a case-by-case examination of the record to determine whether the deviation affected the judgment. 210 This type of individual examination would preclude the categorical acceptance of the initiative process in zoning and would cause undesirable uncertainty about the initiative's availability. Furthermore, the "substantial prejudice" test suggests that the use of the initiative in zoning would be upheld only when the court is satisfied that the same result would have been reached through the conventional zoning process. This test would entirely vitiate the initiative's usefulness, for the device is obviously intended for the purpose of enacting laws that cannot be passed through the conventional legislative process. Moreover, the "substantial prejudice" test is intended for use only in after-the-fact examination, and would not apply where a challenge to the initiative was brought before the election. Defenders of the initiative should instead rely, as suggested liere, on the lack of express or imphied legislative intent to exclude the initiative's use in zoning. ${ }^{211}$

\section{CONCLUSION}

The use of the initiative and referendum im zoning appears compatible with constitutional, statutory, and common law limitations on their scope. The appropriate judicial course would thus be to uphold the use

207. Dicta supporting this argument appear in City of Sausalito v. County of Marin, 12 Cal. App. 3d 550, 559, 90 Cal. Rptr. 843, 848 (1st Dist. 1970) and Bayless v. Limber, 26 Cal. App. 3d 463, 469 n.5, 102 Cal. Rptr. 647, 650 n.5 (2d Dist. 1972). 208. 31 Cal. App. 3d at 64,107 Cal. Rptr. at 227-28.

209. Cal. Code Of Civ. Proc. $\$ 475$ (West 1964).

210. See generally R. Traynor, The RmDLe of liarmLess ERror (1970).

211. This position was relied upon in part in Meridian Development Co. v. Edison Township, 91 N.J. Super. 310, 220 A.2d 121 (1966); however, Meridian's value as authority has been vitiated by the New Jersey Supreme Court's summary affirinance of a contrary decision in Smith v. Township of Livingston, 106 N.J. Super. 444, 256 A.2d 85, aff'd 54 N.J. 525, 257 A.2d 698 (1969). 
of these devices while subjecting all zoning measures to the same judicial scrutiny of substance whether passed by initiative or referendum or by conventional processes. Experience may show that the initiative and referendum do indeed hamper the process of land use planning. An adequate opportumity will then be available to limit these devices. 